\title{
Differential influence of life cycle on growth and toxin production of three Pseudo-nitzschia species (Bacillariophyceae)
}

Sauvey Aurore 1,2, Claquin Pascal 1,2, Le Roy Bertrand 1,2, Le Gac Mickael ${ }^{3}$, Fauchot Juliette 1, 2, *

${ }^{1}$ Normandie Univ; UNICAEN; CNRS; BOREA; 14000 Caen ,France

2 Unité Biologie des Organismes et Ecosystèmes Aquatiques (BOREA); Muséum National d'Histoire

Naturelle; Sorbonne Université; Université de Caen Normandie; Université des Antilles; CNRS; IRD

14000 Caen ,France

3 Ifremer, DYNECO PELAGOS; 29280 Plouzané ,France

*Corresponding author : Juliette Fauchot, email address : juliette.fauchot@unicaen.fr

\begin{abstract}
:
We used a multi-strain approach to study the intra- and interspecific variability of the growth rates of three Pseudo-nitzschia species - P. australis, P. fraudulenta, and P. pungens - and of their domoic acid (DA) production. We carried out mating and batch experiments to investigate the respective effects of strain age and cell size, and thus the influence of their life cycle on the physiology of these species. The cell size - life cycle relationship was characteristic of each species. The influence of age and cell size on the intraspecific variability of growth rates suggests that these characteristics should be considered cautiously for the strains used in physiological studies on Pseudo-nitzschia species. The results from all three species do not support the hypothesis of a decrease in DA production with time since isolation from natural populations. In P. australis, the cellular DA content was rather a function of cell size. More particularly, cells at the gametangia stage of their life cycle contained up to six times more DA than smaller or larger cells incapable of sexual reproduction. These findings reveal a link between $P$. australis life cycle and cell toxicity. This suggest that life cycle dynamics in Pseudo-nitzschia natural populations may influence bloom toxicity.
\end{abstract}

Keywords : domoic acid, cell size, growth, life cycle, Pseudo-nitzschia strains 
ABBREVIATIONS: DA, domoic acid; cDA, cellular domoic acid; dDA, extracellular dissolved domoic acid.

\section{INTRODUCTION}

Diatoms are one of the most common eukaryotic phytoplankton groups in aquatic environments, with approximately 100,000 different species recorded (Not et al. 2012, Mann and Vanormelingen 2013). This ecological success has previously been related to different characteristics of diatoms: the presence of their unique siliceous cell wall, the frustule (Hamm et al. 2003, Armstrong et al. 2009), some metabolic particularities (Allen et al. 2011, Bailleul et al. 2015), important intraspecific diversity (Godhe and Rynearson 2017), and also their unique life cycle (Lewis 1984, 1987). This life cycle is strongly related to variations in cell size, and characterized by two phases: long periods of vegetative multiplication, and short sexual events. During the vegetative phase, cell size decreases over the generations until reaching a minimum non-viable size. This decrease in size is one of the consequences of the presence of the silicified rigid cell wall called a frustule, which is typical of diatoms. While size decreases, vegetative diatom cells are only capable of sexual reproduction within a specific size range corresponding to the gametangia stage. Sexual reproduction then leads production of gametes through meiosis followed by fusion to produce a zygote; then the zygote enlarges to produce a specialized structure called an auxospore allowing for the regeneration of an initial cells of maximum size (Mann 1999, Chepurnov et al. 2004,

This article is protected by copyright. All rights reserved. 
Kaczmarska et al. 2013). The control of sexual reproduction by cell size affects the frequency, the timing, and the importance of sexual reproduction events (D'Alelio et al. 2010, Hense and Beckmann 2015). These in turn probably affect bloom dynamics in natural populations. The link between cell size and life cycle is thus an important characteristic to be explored in diatoms. Furthermore, as far as cell metabolism is concerned, according to allometric laws small cells are generally considered more competent physiologically than larger cells (e.g., thanks to better growth or nutrient acquisition; Edwards et al. 2012, Marañón et al. 2013, Otero et al. 2018), even if some authors reported a decrease in growth rate for smaller cells linked to certain life cycle stages (Chisholm and Costello 1980, Von Dassow et al. 2006). However, the influence of cell size reduction on diatom physiology as related to the life cycle is still poorly documented.

The heterothallic pennate diatoms of the genus Pseudo-nitzschia are cosmopolitan. Fifty species of Pseudo-nitzschia are currently described, out of which 24 are considered to be toxic, i.e., capable of producing domoic acid (DA), a neurotoxin that will accumulate in marine food webs and cause amnesic shellfish poisoning (ASP) events (Lelong et al. 2012 and references therein, Lim et al. 2013, Orive et al. 2013, Fernandes et al. 2014, Teng et al. 2014, 2016, Li et al. 2017, Ajani et al. 2018, Frøsig Gai et al. 2018). According to the literature on different Pseudo-nitzschia species, important interspecific differences in DA cellular content exist (e.g., Pan et al. 1996a,b, Fehling et al. 2004, Howard et al. 2007, Lelong et al. 2012, Thorel et al. 2014, Martin-Jézéquel et al. 2015, Radan and Cochlan 2018). However, a few authors studied several strains per species and also reported significant intraspecific diversity (e.g., Garrison et al. 1992, Villac et al. 1993, Álvarez et al. 2009). Intraspecific diversity in DA production was even higher than interspecific diversity in $P$. multiseries, $P$. calliantha, and $P$. fraudulenta from USA coastal waters (Thessen et al. 2009). In contrast, interspecific differences in DA production were greater than intraspecific 
variability in three $P$. australis, $P$. pungens and $P$. fraudulenta strains from the French coastal waters (Lema et al. 2017). These authors also pointed out that the time spent in culture since isolation might influence Pseudo-nitzschia species physiology, including DA production, as previously reported by Lelong et al. (2012). In addition, previous studies concluded that cell size reduction induced a decrease in DA production in several Pseudo-nitzschia species (Bates et al. 1999, Mafra et al. 2009, Amato et al. 2010).

The objective of this study was therefore to investigate the inter- and intraspecific variability of growth and domoic acid production in three Pseudo-nitzschia species from the French coastal waters, namely $P$. australis, $P$. pungens, and $P$. fraudulenta. We applied a multi-strain approach to grasp intraspecific variability, by studying at least nine strains per species. In addition, we made a special effort to explore the influence of the life cycle on the physiology of each species by studying strains of different cell sizes and the same strains at different sizes during the cell size reduction process. This also allowed us to investigate the influence of strain age on growth and toxin production. Improving knowledge of intraspecific variability in Pseudo-nitzschia species is required for an accurate characterization of the physiology of each species, and thus a better understanding of their harmful bloom dynamics.

\section{MATERIALS AND METHODS}

\section{Strains}

Some Pseudo-nitzschia spp. strains were isolated from natural populations: from the west coast of Brittany and in Arcachon Bay (Atlantic coast, France) for P. australis, and from the Bay of Seine (English Channel, France) for P. pungens and P. fraudulenta. Other strains were obtained by isolating initial cells produced during sexual reproduction experiments (Table 1). Single cells or short chains were isolated using a micropipette, washed three times with filtersterilized $(0.2 \mu \mathrm{m})$ seawater, and incubated in 4-well culture plates in $\mathrm{K} / 2$-medium (Keller et 
al. 1987) enriched in $\mathrm{Si}(54 \mu \mathrm{M})$ at a temperature of $16^{\circ} \mathrm{C}$, an irradiance of $30 \mu \mathrm{mol}$ photons . $\mathrm{m}^{-2} \cdot \mathrm{s}^{-1}$, and a 14:10 L:D light cycle. When the clonal culture was established, it was maintained in $15 \mathrm{~mL}$ ventilated flasks in $\mathrm{K} / 2$-medium $+\mathrm{Si}$ in the same conditions. Cultures were not axenic, but they were periodically checked for bacterial development by optical microscopy observations, and hardly any bacteria were detected. Most Pseudo-nitzschia species were identified from measurements of frustule properties by transmission electron microscopy (TEM) and some by molecular sequencing of the entire internal transcribed spacer region (ITS1-5.8S-ITS2) of the ribosomal RNA (see Lema et al. 2017). For TEM observations, samples were cleaned to remove organic material according to Thorel et al. (2017). To characterize the cell size range of each species, the cell size of each strain was measured every month. The minimum cell size was characterized as the minimum viable size in four $P$. australis strains, six $P$. fraudulenta strains, and six $P$. pungens strains. The strains were observed under a Nikon Eclipse 80i light microscope equipped with a Nikon DS-Ri2 camera, and 20 cells were measured (length and width) using NIS-Elements Imaging Software. Cell apical length (called cell size here) was calculated as the mean \pm standard deviation of each batch of 20 cells (Lundholm et al. 2002).

\section{Experiment 1: Mating experiments}

The main objective of these experiments was to link Pseudo-nitzschia spp. cell size to shifts in life cycle stages, especially by defining the gametangia and the initial cell size ranges. Mating experiments were carried out monthly with $P$. australis, $P$. pungens, and $P$. fraudulenta strains in the course of their cell size reduction process for one year. Strains were considered at the gametangia stage when they were capable of sexual reproduction. These experiments also provided large-size strains from initial cells (F1 strains). Before carrying out the experiments, the cultures (Table 1) were acclimated to the experimental conditions $\left(16^{\circ} \mathrm{C}\right.$, 
$100 \mu \mathrm{mol}$ photons $\cdot \mathrm{m}^{-2} \cdot \mathrm{s}^{-1}$ and 14:10 h L:D light cycle), and 20 cells from each culture were measured. Mating experiments were performed in 6-well culture plates in $5 \mathrm{~mL}$ of $\mathrm{K} / 2$ medium $+\mathrm{Si}$, with an initial concentration of 5,000 cells $\cdot \mathrm{mL}^{-1}$ for each of the two strains of the compatible mating type. The mating type was assessed by crossing the strains with reference strains of known mating types. The strain that bore the auxospores was defined as "PN-", and the other one as "PN+" (Kaczmarska et al. 2013). Plates were incubated in growth chambers at $16^{\circ} \mathrm{C}, 100 \mu \mathrm{mol}$ photons $\cdot \mathrm{m}^{-2} \cdot \mathrm{s}^{-1}$ and $14: 10 \mathrm{~h} \mathrm{~L}: \mathrm{D}$ light cycle (Economic Delux, Snijders Scientific B. V., UK). The crosses were checked daily for the formation of sexual stages (gametes, zygotes, auxospores, or initial cells) under an inverted light microscope (Leica DMIL LED, Wetzlar, Germany). Initial cells were sampled from the successful crosses, and 20 cells were measured (length and width) under a Nikon Eclipse 80i light microscope equipped with a Nikon DS-Ri2 camera using NIS-Elements Imaging Software.

\section{Experiment 2: Batch experiments}

Batch experiments were performed to study two physiological indices, i.e., the growth rate and domoic acid production (cellular domoic acid - cDA - and extracellular dissolved DA dDA - concentrations). The growth rate parameter was estimated during the exponential growth phase, and DA concentrations were measured on the second day of the stationary phase because DA production is higher during this phase before the culture starts declining (Cusack et al. 2002, Fehling et al. 2004, Thessen et al. 2009).

Batch experiments were carried out with Pseudo-nitzschia australis, $P$. pungens, and P. fraudulenta strains (Table 1). Before each experiment, each strain was acclimated to experimental conditions i.e., $16^{\circ} \mathrm{C}, 100 \mu \mathrm{mol}$ photons $\cdot \mathrm{m}^{-2} \cdot \mathrm{s}^{-1}$, and 14:10 h L:D light cycle in growth chambers (Economic Delux, Snijders Scientific B.V., UK). The experiments were

This article is protected by copyright. All rights reserved. 
carried out in $250 \mathrm{~mL}$ filter flasks $\left(\mathrm{NEST}^{\mathrm{TM}}\right)$ with $100 \mathrm{ml}$ of $\mathrm{K} / 2+\mathrm{Si} . \mathrm{Si}(\mathrm{OH})_{4}{ }^{-}$and $\mathrm{PO}_{4}{ }^{2-}$ concentrations were modified to obtain phosphate or silicate limitation in the stationary phase because DA production is obtained in Pseudo-nitzschia cultures after an exponential growth phase followed by quasi-exhaustion of $\mathrm{P}$ or $\mathrm{Si}$ which induces growth arrest (Pan et al. 1996a,b, 1998, Fehling et al. 2004, Amato et al. 2010). Nitrogen, phosphorus, and silicon concentrations in the culture medium were as follows: $400 \mu \mathrm{M} \mathrm{NaNO}, 5 \mu \mathrm{M} \mathrm{KH}_{2} \mathrm{PO}_{4}$, and $125 \mu \mathrm{M} \mathrm{Na}_{2} \mathrm{SiO}_{3}$ for $\mathrm{P}$ limitation, and $400 \mu \mathrm{M} \mathrm{NaNO}_{3}, 25 \mu \mathrm{M} \mathrm{KH}_{2} \mathrm{PO}_{4}$, and $25 \mu \mathrm{M} \mathrm{Na}_{2} \mathrm{SiO}_{3}$ for Si limitation. At the beginning of each experiment, an acclimated culture in the exponential growth phase was centrifuged $\left(10 \mathrm{~min}, 800 \mathrm{~g}, 16^{\circ} \mathrm{C}\right)$ in order to add only cells to the culture medium without affecting nutrient concentrations. The initial cell concentration for all experiments was around $2.5 \cdot 10^{3}$ cells $\cdot \mathrm{mL}^{-1}\left( \pm 0.25 .10^{3}\right)$. Samples were collected once a day in the early afternoon to monitor cell concentrations using a Nageotte counting chamber. At the end of the experiment, each flask still contained at least half of the initial volume of culture.

The growth rate was calculated using the following equation:

$\mu=\frac{\ln \left(X_{2}\right)-\ln \left(X_{1}\right)}{t_{2}-t_{1}}$

Where $\mathrm{t}$ is time in days, and $\mathrm{X}_{1}$ and $\mathrm{X}_{2}$ are cell concentrations (cells $\cdot \mathrm{mL}^{-1}$ ) at $\mathrm{t}_{1}$ and $\mathrm{t}_{2}$, respectively.

On the second day of the stationary phase, samples were taken for DA measurements. A $10 \mathrm{~mL}$ aliquot was taken from each flask, centrifuged, and the supernatant was recovered for extracellular dissolved DA ( $\mathrm{dDA})$ measurements. A second 10-mL aliquot was sonicated on ice with a sonication probe (Bioblock Scientific Vibracell 72442 ultrasons) for 4 min to disrupt cell membranes and release DA from the cells, and filtered on a $0.2-\mu \mathrm{m}$ filter $(33 \mathrm{~mm}$, cellulose acetate membrane). This fraction was used to measure total DA (tDA). The samples This article is protected by copyright. All rights reserved. 
were frozen at $-20^{\circ} \mathrm{C}$ prior to analysis. DA quantification was performed using an ASP ELISA kit (Biosense Laboratories, Bergen, Norway) following the manufacturer's instructions. Each sample was analyzed in duplicate for quality control purposes. The absorbance was measured using a microplate spectrophotometer (iMark ${ }^{\mathrm{TM}}$ Microplate Absorbance Reader, Bio-Rad Laboratories, Inc) equipped with a $450 \mathrm{~nm}$ filter. According to the manufacturer, the calibrated range of the assay is $10-300 \mathrm{pg} \cdot \mathrm{mL}^{-1}$.

The cellular domoic acid content $\left(\mathrm{cDA}, \mathrm{pg} \cdot\right.$ cell $\left.^{-1}\right)$ was calculated from tDA and dDA (in $\mathrm{pg} \cdot \mathrm{mL}^{-1}$ ) normalized to the cell concentration (cells $\cdot \mathrm{mL}^{-1}$ ) as follows:

$c D A=\frac{t D A-d D A}{\text { cell concentration }}$

To characterize interspecific and intraspecific variability in growth and DA production, these batch experiments were performed on multiple strains for each of the three species, i.e., nine Pseudo-nitzschia australis strains, thirteen $P$. pungens strains, and twelve $P$. fraudulenta strains (Table 1). Potential intraspecific variability may originate from genetic variability among strains, but also from the influence of cell size linked to the life cycle or the influence of the time spent in culture. Therefore, we calculated the age of strains isolated from natural populations as the time spent in culture between the date of isolation and the date of each experiment. It is worth noting that we did not take into account F1 strains when we studied the effect of strain age because they were not isolated from natural population. Some strains (four $P$. australis, three $P$. pungens, and four $P$. fraudulenta strains) were also studied at different cell sizes in the course of the size reduction process to estimate the influence of cell size or time in culture (Table 1). Furthermore, we also performed batch experiments on F1 strains and their parent strains to compare their growth rate and DA production and test whether these were inherited characters or influenced by changes in cell size.

This article is protected by copyright. All rights reserved. 


\section{Statistics}

After testing the normality and homoscedasticity of the data, ANOVA was used to test differences in initial size, growth rate, $\mathrm{cDA}$ and $\mathrm{dDA}$ concentrations among the three species using the "car" package in R version 3.5.1. Linear regressions were used to study the effect of cell size or age on the growth rates of Pseudo-nitzschia australis, $P$. pungens, and $P$. fraudulenta strains, and cDA or dDA in $P$. pungens and $P$. fraudulenta cells larger or smaller than $60 \mu \mathrm{m}$, using the "lm" package in R. Multiple linear regression analyses were performed to study the combined effect of cell size and age on growth rate, using the "lm" package in R. Statistical significance was set at $\alpha=0.05$ in all tests.

\section{RESULTS}

\section{Life cycle characteristics}

We characterized the minimum and maximum (initial cells) cell size for each species, along with the size range within which the cells were capable of sexual reproduction - the gametangia size range - to study the influence of the life cycle on Pseudo-nitzschia physiology.

The sizes of the initial cells issued from the mating experiments significantly differed among the three species $(\mathrm{P}<0.001)$. The initial cell sizes ranged from $134 \mu \mathrm{m}$ to $167 \mu \mathrm{m}$ (144 $\mu \mathrm{m}$ on average) for $P$. australis, from $149 \mu \mathrm{m}$ to $183 \mu \mathrm{m}(162 \mu \mathrm{m}$ on average) for $P$. pungens, and from $100 \mu \mathrm{m}$ to $128 \mu \mathrm{m}(113 \mu \mathrm{m}$ on average) for $P$. fraudulenta (Fig. 1).

Globally speaking, the multiple crosses showed that initial cell size was not dependent on parental cell size whatever the species (Fig. 1). The minimum cell size for a species was estimated as the minimum cell size for which cells grew in culture. This mean minimum cell size was $29.5 \mu \mathrm{m} \pm 1.7$ for $P$. australis, $32.6 \mu \mathrm{m} \pm 1.4$ for $P$. pungens, and $22.3 \mu \mathrm{m} \pm 0.8$ for P. fraudulenta (Fig. 2). These values corresponded to $17.6 \% \pm 1.0,17.8 \% \pm 0.8$, and $17.5 \%$ 
\pm 0.6 of the maximum initial cell size, respectively. Microscopic observations revealed abnormal valve shapes in small-sized cells (Fig. S1 in the Supporting Information).

Gametangia sizes ranged from 55 to $85 \mu \mathrm{m}, 43$ to $75 \mu \mathrm{m}$, and 29 to $90 \mu \mathrm{m}$ in Pseudonitzschia australis, $P$. pungens, and $P$. fraudulenta, respectively. These sizes corresponded to $33-51 \%, 23-41 \%$, and $27-70 \%$ of the maximum initial cell sizes, respectively (Fig. 2). These results mean that $P$. fraudulenta cells were at the gametangia stage for $57.5 \%$ of their life cycle, $P$. australis for only $21.6 \%$, and $P$. pungens $21.3 \%$, even if these evaluations may have been influenced by variation in division rate with cell size (D'Alelio et al. 2009). These size ranges corresponded to gametangia capable of producing new initial cells through sexual reproduction. However, the mating experiments revealed that slightly smaller or larger cells were also able to produce gametes that fused to form zygotes; yet, in these parental cell sizes, the resulting auxospores did not fully develop and therefore did not produce initial cells (Fig. 2).

Growth rate: influence of strain age and cell size

The growth rate of Pseudo-nitzschia australis, P. pungens and P. fraudulenta spanned from 0.31 to $0.82 \cdot \mathrm{d}^{-1}, 0.15$ to $0.75 \cdot \mathrm{d}^{-1}$ and 0.19 to $0.68 \cdot \mathrm{d}^{-1}$, respectively (Fig. 3B). These results show great intraspecific variability in growth rate in Pseudo-nitzschia spp., while no significant difference among the three species emerged. The high diversity of the strains in terms of cell size and age allowed us to explore the relative influence of these two parameters on the growth rate. Even if globally older strains tended to be characterized by smaller cells, there was no simple and direct relationship between the cell size and the age when considering all strains used for one species. Since all strains were not isolated at the same cell size, some strains of the same age exhibited different cell sizes (Fig. S2 in the Supporting Information).

This article is protected by copyright. All rights reserved. 
In Pseudo-nitzschia australis, $P$. pungens and, $P$. fraudulenta, the growth rate decreased significantly with age $(\mathrm{P}<0.001$, Fig. 3A). However, in $P$. pungens and $P$. fraudulenta, we did not study strains of all ages, but rather two groups corresponding to two sampling periods (2011-2012 and 2016; Table 1). Therefore, some strains were more than 40 months old, and others were less than 10 months old. For these two species, although globally growth rate decreased with age, it is worth nothing that no tendency of growth rate evolution as a function of age emerged in either of these two groups taken separately (Fig. 3A).

Globally, for the three species, growth rates were always lower for cell size below 60 $\mu \mathrm{m}$ (Fig. 3B). However, beyond this general tendency, the relationship between cell size and growth rates were species specific. There was no relationship between cell size and growth rate in Pseudo-nitzschia fraudulenta, except the difference below and above this threshold of $60 \mu \mathrm{m}$. In $P$. pungens, the growth rate decreased linearly with cell sizes above $60 \mu \mathrm{m}$, but below this size there was no significant tendency of growth evolution with cell size except that growth rates were the lowest. Finally, in P. australis, the growth rate significantly decreased with cell size $(\mathrm{P}<0.001$ above and below $60 \mu \mathrm{m})$. However, the decrease was more pronounced when cell sizes were below $60 \mu \mathrm{m}$ (Fig. 3B).

In each strain cell size decreased with age, as in all diatom cultures, so we used multiple linear regression analyses to discriminate the effect of age from the effect of cell size on the measured growth rates (equations $1 \mathrm{~A}, 1 \mathrm{~B}, 2$, and 3).

(1A) Pseudo-nitzschia australis, size $<60 \mu \mathrm{m}: \mu=-0.5113+0.0225 *$ Size $(\mathrm{P}<0.001)$

(1B) Pseudo-nitzschia australis, size $>60 \mu \mathrm{m}: \mu=0.3847+0.0028 *$ Size $(\mathrm{P}<0.001)$

(2) Pseudo-nitzschia pungens: $\mu=0.4563-0.0051 *$ Age $+0.0014 *$ Size $(\mathrm{P}<0.001)$

(3) Pseudo-nitzschia fraudulenta: $\mu=0.6093-0.00481 *$ Age $(\mathrm{P}<0.001)$

This article is protected by copyright. All rights reserved. 
Even if Pseudo-nitzschia australis, growth rate decreased with age and cell size taken separately, the results of this statistical approach show that $P$. australis growth rate could be predicted from cell size alone. $P$. australis strains of different ages exhibited similar growth rates (e.g., around $0.60 \cdot \mathrm{d}^{-1}$ for 9-month-old or 21-month-old strains), while strains of the same age grew at different rates (e.g., 0.60 or $0.30 \cdot \mathrm{d}^{-1}$ for 20 month-old strains; Fig. 3A). In contrast, the largest $P$. australis strains $(>60 \mu \mathrm{m})$ had the highest growth rates $\left(>0.60 \cdot \mathrm{d}^{-1}\right)$, and the strains whose cell size was below $45 \mu \mathrm{m}\left(<0.45 \cdot \mathrm{d}^{-1}\right.$; Fig. 3B $)$ had the lowest. In $P$. pungens, the growth rate was a function of both cell size and age. The growth rate decreased from around 0.60 to $0.15-0.38 \cdot \mathrm{d}^{-1}$ between young (less than 10 months old) and older $P$. pungens strains (more than 40 months old). But these changes in growth rate in $P$. pungens were also linked to changes in cell size: the strains whose cell size was above $60 \mu \mathrm{m}$ exhibited the highest growth rates, while smaller strains grew slower (Fig. 3B). In contrast, the growth rate of $P$. fraudulenta was only a function of the strain age. For example, the growth rate was between 0.52 and $0.59 \cdot \mathrm{d}^{-1}$ for strains less than 10 months old, but between 0.19 and $0.44 \cdot \mathrm{d}^{-1}$ for more than 50-month-old P. fraudulenta (Fig. 3A).

\section{The life cycle influences toxicity}

All the strains of all three species produced domoic acid under our experimental conditions. Whatever the species, there was no significant difference in domoic acid cellular content (cDA) between phosphate limitation and silicate limitation (Fig. S3 in the Supporting Information). Even if, for each strain considered individually, cDA could be higher under Si or P limitation (data not shown), there was no global tendency for one limitation to promote higher DA production. In contrast, we measured significant differences among species, with $P$. pungens maximum cDA one order of magnitude above $P$. fraudulenta maximum cDA, and

This article is protected by copyright. All rights reserved. 
$P$. australis maximum cDA also one order of magnitude above $P$. pungens maximum cDA (P $<0.001$; Fig. S3).

Figures 4 and 5 show cDA and dDA for the three species, respectively. In Pseudonitzschia australis, $P$. pungens, and P. fraudulenta, cDA was between 12 and $645 \mathrm{fg} \cdot \mathrm{cell}^{-1}$, 0.2 and $50 \mathrm{fg} \cdot \mathrm{cell}^{-1}$, and 0.03 and $5.6 \mathrm{fg} \cdot \mathrm{cell}^{-1}$, respectively (Fig. 4, A and B). In these three species, $\mathrm{dDA}$ was between 0.022 and $8 \mathrm{ng} \cdot \mathrm{mL}^{-1}, 0.04$ and $0.395 \mathrm{ng} \cdot \mathrm{mL}^{-1}$, and 0.03 and $0.215 \mathrm{ng} \cdot \mathrm{mL}^{-1}$, respectively (data not shown). When considering the biomass in the cultures, dDA concentrations corresponded to $1-5,970 \mathrm{fg} \cdot$ cell $^{-1}$ for $P$. australis, $4-90 \mathrm{fg} \cdot \operatorname{cell}^{-1}$ for $P$. pungens, and 0.05-10 fg $\cdot$ cell $^{-1}$ for $P$. fraudulenta (Fig. 5, A and B). The measured dDA concentrations significantly differed among the three species $(\mathrm{P}<0.001)$. Pseudo-nitzschia australis produced the highest amounts of dDA, followed by $P$. pungens, and then $P$. fraudulenta (Fig. 5, A and B).

cDA and dDA concentrations were not significantly influenced by strain age in Pseudo-nitzschia pungens and $P$. fraudulenta, even if we measured a few higher cDA concentrations in some of the young strains and if no data is available for age between 6 and 40 months (Fig. S4B, S5, A and B). In P. australis, cDA concentrations increased when the strains were between 5 and 12 months old (Fig. S4A). However, this increase in cDA seemed to be rather related to $P$. australis cell size (Fig. 4A). The cell size did not affect cDA concentrations in $P$. fraudulenta (Fig. 4B), while dDA concentrations in this species were significantly higher (although very low) in some strains with cell sizes above $75 \mu \mathrm{m}(\mathrm{P}<$ 0.05; Fig. 5B). Measured dDA concentrations in $P$. pungens were not related to cell size (Fig. 5B). There was no clear relationship between cDA concentrations and $P$. pungens cell size (Fig. 4B). However, we recorded the highest cDA concentrations for this species ( $>20 \mathrm{fg}$ • cell $^{-1}$ ) only in the large strains $(>70 \mu \mathrm{m})$, although some large-size strains also exhibited very low cDA concentrations. Furthermore, no clear relationship appeared between the cDA or 
dDA concentrations in F1 strains as compared to their parental strains whatever the species (data not shown).

There was a strong relationship between DA and cell size in Pseudo-nitzschia australis. Measured cDA concentrations varied with cell size following a Gaussian model (P $<0.001$; Fig. 4A):

(4) $c D A=524 * e^{\left(-0,5 *\left(\frac{\text { Size }-71}{18}\right)^{2}\right)}$

cDA concentrations increased from 130 to $425 \mathrm{fg} \cdot$ cell $^{-1}$ as cell size decreased from $\sim 130$ to $80 \mu \mathrm{m}$. Maximum cDA concentrations were between 600 and $645 \mathrm{fg} \cdot$ cell $^{-1}$ for cell sizes between 62.7 and $69.1 \mu \mathrm{m}$. The Gaussian model gave a maximum cDA concentration for 71$\mu \mathrm{m}$ cells. Below $60 \mu \mathrm{m}$, cDA concentrations decreased down to $10 \mathrm{fg} \cdot$ cell $^{-1}$ (Fig. 4A). These results were confirmed by monitoring four Pseudo-nitzschia australis strains whose cDA concentrations followed the Gaussian model over time while the cells were decreasing in size (Fig. 6). These results show that large $(100-130 \mu \mathrm{m})$ and small $(40-30 \mu \mathrm{m})$ P. australis strains could present cDA concentrations comparable to those of $P$. pungens strains (Fig. 4). Therefore, the difference in cDA between $P$. australis and the other two species was greater in the size range around 50-100 $\mu \mathrm{m}$. Furthermore, in P. australis, measured dDA concentrations also increased in $70-100 \mu \mathrm{m}$ strains (Fig. 5A). It is interesting to note that the cell size range for which cDA concentrations were higher in $P$. australis coincided with the size range characteristic of gametangial cells capable of sexual reproduction for this species (55-85 $\mu \mathrm{m}$, Fig. 2). dDA concentrations were also higher in the upper part of the gametangial cell size range $(70-85 \mu \mathrm{m})$.

This article is protected by copyright. All rights reserved. 


\section{DISCUSSION}

Using a multi-strain approach for three Pseudo-nitzschia species, we studied the intra- and interspecific variability of growth rates and toxicity. This approach made it possible to disentangle the respective effects of strain age and cell size. Furthermore, taking into account cell size offered a unique perspective on the influence of the life cycle on the physiology of Pseudo-nitzschia species.

Cellular and dissolved domoic acid production in Pseudo-nitzschia australis, P. pungens, and $\mathrm{P}$. fraudulenta

Pseudo-nitzschia species are not all systematically toxic, and even among toxic species some strains may not be able to produce DA (Lelong et al. 2012). Previous studies on strains of different geographic origins reported great variability in cDA concentrations in $P$. pungens and $P$. fraudulenta. Although P. fraudulenta has sometimes been reported to be a nonproducer of DA (Hasle 2002, Thessen et al. 2009, Quijano-Scheggia et al. 2010), our $P$. fraudulenta strains exhibited cDA concentrations between 0.03 and $5.6 \mathrm{fg} \cdot$ cell $^{-1}$. These concentrations are similar to those reported in the review by Trainer et al. (2012; up to $30 \mathrm{fg}$. cell $^{-1}$ ) and in Lema et al. (2017; up to $55 \mathrm{fg} \cdot$ cell $\left.^{-1}\right)$, though in the lower range of concentrations. For $P$. pungens, in contrast with studies reporting non-toxigenic strains (Villac et al. 1993, Bates et al. 1998 and references therein), each of our strains produced DA, even if the measured cDA concentrations $\left(0.2-50 \mathrm{fg} \cdot\right.$ cell $\left.^{-1}\right)$ were also in the lower range compared with previous studies (Bates et al. 1998, Baugh et al. 2006, Calu et al. 2009, Rhodes et al. 2013, Lema et al. 2017). Pseudo-nitzschia pungens and P. fraudulenta also consistently produced dissolved domoic acid. To our knowledge, this is the first report of dDA production by $P$. fraudulenta, in contrast with Baugh et al. (2006) and Lema et al. (2017) who did not detect dDA production by this species. As for cDA, our results confirm 
variability in $\mathrm{dDA}$ production among $P$. pungens strains, in agreement with previous studies. Lema et al. (2017) did not detect any dDA in their P. pungens cultures, while Baugh et al. (2006) measured dDA levels similar to the lowest concentrations measured in the present study (at similar cell concentrations).

Pseudo-nitzschia australis produced the highest cDA concentrations (between 12 and $\left.645 \mathrm{fg} \cdot \mathrm{cell}^{-1}\right)$, in the same range as those already measured in strains isolated on French coasts (maximum between 30 and $700 \mathrm{fg} \cdot$ cell $^{-1}$; Thorel et al. 2014, Martin-Jézéquel et al. 2015, Lema et al. 2017), but much lower than in strains isolated in Ireland (up to 26,000 $\mathrm{fg}$. cell $^{-1}$; Cusack et al. 2002) and in the East Pacific coastal waters (up to $1,740 \mathrm{fg} \cdot$ cell $^{-1}$ in Chile, Álvarez et al. 2009; up to $1,870 \mathrm{fg} \cdot$ cell $^{-1}$ in Baja California, Santiago-Morales and García-Mendoza 2011; and up to 37,000 $\mathrm{fg} \cdot$ cell $^{-1}$ in California, Garrison et al. 1992). These differences in toxicity may point out the existence of different $P$. australis ecotypes with contrasting capacities of DA production, as previously shown for other Pseudo-nitzschia species by Thessen et al. (2009). In the present study, $P$. australis also produced the highest dDA concentrations, in accordance with previous reports by Maldonado et al. (2002; up to $\left.7.6 \mathrm{ng} \cdot \mathrm{mL}^{-1}\right)$, Martin-Jézéquel et al. (2015; up to $\left.20.1 \mathrm{ng} \cdot \mathrm{mL}^{-1}\right)$, and Lema et al. $(2017 ; 430$ $\left.\mathrm{fg} \cdot \operatorname{cell}^{-1}\right)$.

These results confirm the high interspecific variability in DA production already highlighted by Lelong et al. (2012). More particularly, the gradation in toxicity between Pseudo-nitzschia fraudulenta, $P$. pungens, and $P$. australis already observed by Lema et al. (2017) on strains from the same area confirms the hypotheses from an in situ study in the English Channel relating bloom toxicity to Pseudo-nitzschia species diversity (Thorel et al. 2017). However, our results show that the most toxic $P$. pungens strains are as toxic as some P. australis strains. Therefore $P$. pungens also has to be considered when dealing with DA

This article is protected by copyright. All rights reserved. 
toxic events observed in French coastal waters, particularly in the English Channel where $P$. australis is mainly pointed out (Klein et al. 2010, Thorel et al. 2017).

Only few studies present dDA measurements during blooms (e.g., Bargu et al. 2008), while impacts on marine organisms have already been documented (Liu et al. 2007). All our strains produced dDA at significant concentrations, even if the extrapolation of dDA concentrations obtained in culture to in situ bloom situations is uncertain. Increased knowledge regarding this parameter is required to grasp its impact on marine ecosystems.

Life cycle characteristics in relation to cell size and consequences on sexual reproduction in natural populations

We characterized the link between cell size and life cycle stages in Pseudo-nitzschia australis, $P$. pungens, and $P$. fraudulenta by determining initial cell size, the vegetative cell size range, and the gametangia size range. As reported in the literature (Chepurnov et al. 2004, Kaczmarska et al. 2013), these cardinal points of the diatom life cycle were clearly species-specific. The initial cell sizes were between $134 \mu \mathrm{m}$ and $167 \mu \mathrm{m}$ for P. australis, 149 $\mu \mathrm{m}$ and $183 \mu \mathrm{m}$ for $P$. pungens, and $100 \mu \mathrm{m}$ and $128 \mu \mathrm{m}$ for $P$. fraudulenta. To our knowledge, this is the first report of initial cell size for $P$. fraudulenta. However, the initial cell size range can be even larger in this species: Cusack et al. (2004) reported vegetative cells greater than $128 \mu \mathrm{m}$. Pseudo-nitzschia pungens initial cell sizes are in agreement with those found by Chepurnov et al. (2005). Moreover, in P. australis and P. pungens, these sizes are similar to the initial cell sizes measured during a sexual reproduction event observed in situ during a bloom in Washington coastal waters (Holtermann et al. 2010). The relationship between the size of parental cells and the initial cell size has been studied in different pennate and centric diatoms. Some authors report a linear relationship both in centric (Jewson 1992) and pennate diatoms (Davidovich 1994, Edlund and Bixby 2001, Davidovich et al. 2010). 
However, Armbrust and Chisholm (1992), Davidovich (1994) and Fuchs et al. (2013) observed no relationship between parental size and initial cell sizes in Thalassiosira weissflogii, Fragilariopsis kerguelensis, and Synedra tabulata, respectively. In the present study, the initial cell size was also independent of the parent cell size in all three Pseudonitzschia species within the studied size range.

Minimum sizes were $28 \mu \mathrm{m}, 31 \mu \mathrm{m}$, and $22 \mu \mathrm{m}$ in Pseudo-nitzschia australis, $P$. pungens, and $P$. fraudulenta, respectively. These values are close to those obtained for $P$. pungens $(25-30 \mu \mathrm{m})$ by Chepurnov et al. (2005) or for P. arenysensis $(\sim 18 \mu \mathrm{m})$ in a laboratory study (Amato et al. 2005) and with a model of size reduction (Schwarz et al. 2009). Interestingly, the minimum cell size corresponded to $17.6 \% \pm 0.8$ of the maximum initial size for the three species. It could be interesting to explore if this threshold of $17 \%$ is valid for other diatom species. These very small cells are rarely observed in situ and may not be representative of natural populations for physiological studies.

The gametangia size ranges observed in this study are in accordance with the size range favorable to sexual reproduction usually admitted for diatoms ( 30-75\%; Mann et al. 2003, Chepurnov et al. 2004, Von Dassow et al. 2006, Davidovich et al. 2012, Fuchs et al. 2013, Vanormelingen et al. 2013). The three species presented closed gametangia size ranges, since the cells lost their ability to reproduce sexually before reaching the minimum viable cell size (Chepurnov et al. 2004). These gametangia size ranges fall within previous ranges measured for Pseudo-nitzschia species: 20-90\% for P. arenysensis (Amato et al. 2005), 2370\% for P. multiseries (Hiltz et al. 2000), 39-71\% for P. multistriata (D'Alelio et al. 2009), although $P$. australis and $P$. pungens presented narrower gametangia size ranges. For example, Chepurnov et al. (2005) found that their P. pungens strains could mate in a wider size range (20-60\% of initial cell size, according to their data), even if their strains belonged to the same clade as ours (clade I; Lim et al. 2014). When gametangia size ranges are 
narrower, it can be hypothesized that a smaller portion of the population is capable of sexual reproduction in natural populations. This may affect encounter rates during blooms, and in turn reproductive success. However, the fact that only a small portion of the population can sexually reproduce may also be an ecological advantage regarding competition with the rest of the phytoplankton community because most of the Pseudo-nitzschia population would carry on with vegetative multiplication during a sexual reproduction event (Lewis 1984). Furthermore, in $P$. australis and $P$. pungens, the narrower gametangia size range is linked to the fact that vegetative cells need to decrease more in size to reach the gametangia stage. These life cycle characteristics probably affect the frequency and the timing of sexual reproduction events in natural populations (Lewis 1984). The difference in gametangia size range observed in the three species therefore suggests that their natural populations could present different sexual reproduction dynamics. This in turn could influence the general population and bloom dynamics (Jewson 1992, Edlund and Stoermer 1997, D'Alelio et al. 2010).

This study highlights an intermediate stage of the Pseudo-nitzschia life cycle. Our experiments revealed a size range wider than that of gametangia, within which cells were capable of gametogenesis and fertilization but could not produce initial cells. This second size range observed for the first time in this study suggests that the metabolic changes linked to the transition from vegetative cells to gametangia occur progressively during the decrease in cell size allowing cells to acquire the ability to reproduce sexually. When entering the larger size range, cells seem to acquire the physiological abilities required for pairing, gametogenesis, and fertilization. This may include production of pheromones for the recognition of complementary sexual types (Sato et al. 2011, Gillard et al. 2013, Frenkel et al. 2014), and mobility abilities for active pairing. In addition, in the larger size range, cells must be physiologically ready for meiosis which leads to gametogenesis (diatom are diplonts).

This article is protected by copyright. All rights reserved. 
Then, as the cells enter the narrower size range, they probably acquire supplementary physiological abilities that enable them to ensure complete auxosporulation. This process represents a high metabolic cost for the cells: they probably stop most syntheses during at least the first steps of sexual reproduction that lasts two to four days on average in Pseudonitzschia species (Davidovich and Bates 1998; A. Sauvey unpub. data). The zygote also needs lots of storage to restore a new large initial cell (Chepurnov et al. 2005). Therefore, in contrast to cells in the larger size range, gametangial cells in the narrower range may present a more efficient metabolism with higher storage capabilities - especially for silicium - to be able to synthesize the frustule of the new initial cell. These results stress the fact that gametangial cells probably present particular metabolic characteristics as compared to vegetative cells.

Differential influence of life cycle stages and strain age on growth and DA production in Pseudonitzschia species

The time spent in culture seemed to influence Pseudo-nitzschia fraudulenta and P. pungens growth since growth rates decreased with increasing strain age. However, the strains had been isolated during two distant sampling periods, so it is difficult to tell whether this difference was a consequence of cell adaptation to natural environmental conditions (i.e., the difference reflected the period when the population from which the strains were isolated) or a physiological change during the culturing period (i.e., the difference reflected strain age; Lakeman et al. 2009). Further studies with strains of complementary ages are needed to state on this point. However, these results highlight that it is important to take into account the fact that strains in culture can evolve, so that ecophysiological studies should be performed as soon as possible ( $\leq 1$ or 2 years) after Pseudo-nitzschia strains have been isolated.

This article is protected by copyright. All rights reserved. 
In Pseudo-nitzschia australis, the link between growth rate and strain age was probably the outcome of the weak relationship between age and cell size since cell size was sufficient to predict the growth rate. The same relationship was observed for the three species, with a sharp decrease in growth rate below a cell size threshold of $60 \mu \mathrm{m}$. Above this size, growth rates were similar in all $P$. fraudulenta strains whatever the cell size. However, above $60 \mu \mathrm{m}$ in $P$. pungens and $P$. australis, the growth rate also decreased with cell size, although more slowly. Altogether, the growth rate decreased with decreasing cell size. This result is in contradiction with allometric rules generally accepted for phytoplankton populations. These rules predict an increase of growth rates with decreasing cell size due to higher surface-to-volume ratios that, for example, favor higher nutrient uptake (Amato et al. 2005, Von Dassow et al. 2006a, Edwards et al. 2012, Marañón et al. 2013, Otero et al. 2018). Our results therefore show that allometric rules do not apply when dealing with intraspecific diversity in Pseudo-nitzschia species. The distinctive feature of the size-growth relationship for our three Pseudo-nitzschia species is the sharp decrease of the growth rate in small cells. Similar results have been reported for Thalassiosira species (Chisholm and Costello 1980, Von Dassow et al. 2006). These authors related the decrease of the growth rate in small cells to sexual reproduction. In contrast, in the present study, the lowest growth rates did not coincide with gametangia size ranges, and might rather represent a decrease in metabolism efficiency when cells approached their minimum viable size. Emphasizing this point, we often observed cells studied here displayed abnormal valve shapes in the smallest-size strains (data not shown), suggesting deficient valve deposition as reported by Von Dassow et al. (2006). In natural populations, the fact that small cells may be physiologically less efficient could explain why these size ranges are rarely observed: small cells may not be competitive enough to outcompete larger cells and survive. Consequently, it is important to pay attention to cell size in addition to strain age. Strains of large to medium cell sizes ( $\geq$ gametangia sizes)

This article is protected by copyright. All rights reserved. 
should be used for ecophysiological studies on Pseudo-nitzschia species. Furthermore, choosing strains of similar cell sizes appears to be an important prerequisite for comparative (inter- or intraspecific) studies.

As far as domoic acid (cDA and $\mathrm{dDA}$ ) production is concerned, strain age had no significant influence in the three species. However, a few young Pseudo-nitzschia pungens strains presented higher cDA concentrations than the others, whatever their age. Beyond inter-specific differences, this could explain why a decrease in cDA with time in culture was previously reported in the literature (Lelong et al. 2012 and references therein), in contrast with the present results.

As for the influence of cell size, we found the highest dDA concentrations in some large Pseudo-nitzschia fraudulenta F1 strains, and the highest cDA concentrations in some large $P$. pungens strains. However, there was no clear evidence of an influence of cell size on $P$. fraudulenta and $P$. pungens DA production since large strains of these two species also exhibited very low cDA and dDA concentrations. These results do not confirm that DA production systematically decreases with decreasing cell size, as reported in $P$. multiseries and P. multistriata (Bates et al. 1999, Mafra et al. 2009, Amato et al. 2010). However, they are not completely in disagreement for some strains, stressing once more the high intraspecific variability characteristic of Pseudo-nitzschia species. This great variability was also highlighted by the cDA and $\mathrm{dDA}$ concentrations measured in the F1 strains, which were not related to concentrations in parental strains. This result is in agreement with Amato et al. (2010), who studied P. multistriata and concluded that the inheritance of the ability to produce DA was not a simple Mendelian process.

Our results revealed that cDA concentrations could be predicted from cell size by a Gaussian model in Pseudo-nitzschia australis. This is not completely in contradiction with previous results reporting a decrease in cDA with decreasing cell size (Bates et al. 1999,

This article is protected by copyright. All rights reserved. 
Mafra et al. 2009, Amato et al. 2010). Our cell size range was greater than in any other study because we took into account very large strains issued from initial cells obtained in mating experiments. In the literature, the decrease in cDA corresponds to sizes ranging from medium-sized to small cells (Bates et al. 1999, Mafra et al. 2009, Amato et al. 2010). We also observed a decrease in cDA with decreasing cell size in P. australis within that same size range. In addition, we brought supplementary information to currently available data about the relationship showing that showing that medium-sized cells are the most toxic ones and large cells issued from sexual reproduction present cDA concentrations comparable to small cells. These observations show that cDA concentrations are not linearly related to cell size in P. australis. Furthermore, the evolution of cDA and dDA concentrations suggests that they are not characteristic of any given strain because DA production is not stable over a whole life time in P. australis, in contrast to results reported for P. multistriata (Amato et al. 2010). This discrepancy highlights the fact that (i) the relationship between cell size and DA production is species-specific, and (ii) it is important to study the whole size range of a species before drawing conclusions on this relationship.

The striking result of this study is that the increase in cDA in Pseudo-nitzschia australis coincided with the size range within which the cells reached the gametangia stage, while dDA also increased in the larger gametangial cells. We can therefore hypothesize that the physiological changes occurring when vegetative cells become sexualized also result in an increase of DA production. During the sexual reproduction process (gametogenesis, fertilization, and auxosporulation), the cells cannot carry out photosynthesis and probably other metabolic pathways any more. Preparing vegetative cells for this step probably includes increasing cell metabolism efficiency and/or modifications of metabolic pathways to increase cellular quotas of/ the required cellular metabolites (Pan et al. 1998). This probable reorientation of the metabolism may also favor DA synthesis pathways. Bates et al. (1999)

This article is protected by copyright. All rights reserved. 
hypothesized that the ability of cells to produce domoic acid was not related to cell size but to general physiological changes. Our results suggest that these physiological changes can be linked to the life cycle and especially the sexualization of vegetative cells, at least for $P$. australis. Domoic acid synthesis pathways involve the Krebs cycle and the formation of derived compounds (e.g., glutamate and geranyl pyrophosphate; Pan et al. 1998, Brunson et al. 2018). We can hypothesize that in P. australis the change in metabolism that the cells undergo for their sexualization affects these metabolic pathways, resulting in an increase in DA production. Therefore, the increase in DA cellular content in gametangia cells might be a "physiological coincidence". However, the role of this toxin still remains to be deciphered, so we can also wonder if DA could play a role in P. australis sexual reproduction. In pennate diatoms, interactions between sexualized cells are needed to trigger gametogenesis. The increased production of DA (and especially dissolved DA) therefore raises questions on the potential role of this toxin as a pheromone (previously mentioned by Lelong et al. 2012). Interestingly, the only pheromone identified in a pennate diatom up to now is a cyclic dipeptide derived from proline, whose synthesis is thus linked to amino acid biosynthesis (Guillard et al. 2013, Frenkel et al. 2014). It is however surprising that a similar link between DA production and life cycle was not found in the two other Pseudo-nitzschia species which present the same sexual reproduction pattern. In addition, cells may be more vulnerable during sexual reproduction, so domoic acid could act as a grazer deterrent: its production has been shown to increase in the presence of copepods (Harðardóttir et al. 2015, Tammilehto et al. 2015). Finally, different studies also showed an allelopathic effect of Pseudo-nitzschia or DA addition on different phytoplankton species (Lundholm et al. 2005, Smeti et al. 2015, Sobrinho et al. 2017, Van Meerssche et al. 2018). Higher DA production may therefore also represent an ecological advantage that could offset the growth arrest/decrease during sexual events in Pseudo-nitzschia blooms.

This article is protected by copyright. All rights reserved. 
The link between DA and cell size, and therefore DA and life cycle stages, suggests that Pseudo-nitzschia australis life cycle probably impacts bloom toxicity. First, P. australis populations can be more or less toxic depending on their cell size spectra. Cell size distribution varies across years in natural populations (D'Alelio et al. 2010), this might partly explain inter-annual variations in bloom toxicity. Furthermore, when a sexual event occurs in a natural population, it results in the production of initial cells and thus in a shift in size distribution towards large cells (Holtermann et al. 2010). During a $P$. australis bloom, this process is expected to result in a decrease in DA concentration in the population, especially as the large cells with slightly higher growth rates will progressively outnumber smaller cells in this population (Armbrust and Chisholm 1992). Life cycle events could therefore also impact DA concentrations in natural populations at the scale of a bloom.

\section{CONCLUSIONS}

This study characterizes the toxicity and cell size - life cycle relationship in three Pseudonitzschia species. Even if we evidenced species-specific characteristics, the importance of intra-specific variability proves that the number of studied strains per species greatly influences the conclusions on Pseudo-nitzschia physiology. Furthermore, our results advocate for the use of Pseudo-nitzschia strains not more than one or two years after their isolation, and of cell sizes at or above gametangia size when studying cellular metabolism. However, as far as toxicity is concerned, our results do not support the hypothesis of a decrease in DA production with time in culture in these three species. Most importantly, this study shows that P. australis cDA can be predicted from cell size by a non-linear relationship. In this species, cDA is maximum in medium-sized cells at the gametangia stage of their life cycle. These results suggest that either the metabolic changes occurring in gametangia cells favor DA production as compared to vegetative cells, or that DA is involved in sexual reproduction. 
The Pseudo-nitzschia life cycle may therefore influence the toxicity of blooms. Furthermore, the cell size - cDA relationship revealed by our results may be useful to predict bloom toxicity based on the cell size spectra of a $P$. australis population. Finally, a comparative understanding of the cellular metabolism of $P$. australis at different life cycle stages may help to identify the DA biosynthesis pathway.

\section{ACKNOWLEDGEMENTS}

The authors thank Dr. Didier Goux for his assistance with species identification by TEM, the BOREA laboratory staff for help with the experiments and Annie Buchwalter for English corrections. We are most grateful to Dr. Catherine Dreanno for identification by sequencing of Pseudo-nitzschia strains. We thank Dr. Amandine Caruana (Ifremer, Laboratoire Phycotoxines, Nantes, France), Dr. Elisabeth Nézan, and Dr. Nicolas Chomérat (Ifremer, LER/BO, Concarneau, France) for a $P$. australis parental strain. We also thank the two anonymous reviewers for their comments and suggestions that helped improve the manuscript. This work was supported by the PseudoPhy project (2015-2019) funded by Agence de l'eau Seine-Normandie and by an INSU EC2CO (France) grant. Aurore Sauvey received a PhD fellowship from the Ministère de la Recherche et de l'Enseignement Supérieur, and this paper is part of her Ph.D. thesis.

\section{REFERENCES}

Ajani, P.A., Verma, A., Lassudrie, M., Doblin, M.A. \& Murray, A. 2018. A new diatom species $P$. hallegraeffii sp. nov. belonging to the toxic genus Pseudo-nitzschia (Bacillariophyceae) from the East Australian Current. PLOS ONE 13:e195622.

Allen, A.E., Dupont, C.L., Obornik, M., Horak, A., Nunes-Nesi, A., McCrow, J.P., Zheng, H., Johnson, D.A., Hu, H., Fernie, A.R. \& Bowler, C. 2011. Evolution and metabolic significance of the urea cycle in photosynthetic diatoms. Nature. 473:203.

Álvarez, G., Uribe, E., Quijano-Scheggia, S., López-Rivera, A., Mariño, C. \& Blanco, J. 2009.

This article is protected by copyright. All rights reserved. 
Domoic acid production by Pseudo-nitzschia australis and Pseudo-nitzschia calliantha isolated from North Chile. Harmful Algae 8:938-45.

Amato, A., Orsini, L., D’Alelio, D. \& Montresor, M. 2005. Life cycle, size reduction patterns, and ultrastructure of the pennate planktonic diatom Pseudo-nitzschia delicatissima (Bacillariophyceae). J. Phycol. 41:542-56.

Amato, A., Kooistra, W.H., Ghiron, J.H.L., Mann, D.G., Pröschold, T. \& Montresor, M. 2007. Reproductive isolation among sympatric cryptic species in marine diatoms. Protist 158: 193 207.

Amato, A., Lüdeking, A. \& Kooistra, W.H.C.F. 2010. Intracellular domoic acid production in Pseudo-nitzschia multistriata isolated from the Gulf of Naples (Tyrrhenian Sea, Italy). Toxicon 55:157-61.

Armbrust, E.V. \& Chisholm, S.W. 1992. Patterns of cell size change in marine centric diatom: variability evolving from clonal isolates. J. Phycol. 28:146-56.

Armstrong, R.A., Peterson, M.L., Lee, C. \& Wakeham, S.G. 2009. Settling velocity spectra and the ballast ratio hypothesis. Deep. Res. Part II Top. Stud. Oceanogr. 56:1470-8.

Bailleul, B., Berne, N., Murik, O., Petroutsos, D., Prihoda, J., Tanaka, A., Villanova, V., Bligny, R., Flori, S., Falconet, D., Krieger-Liszkay, A., Santabarbara, S., Rappaport, F., Joliot, P., Tirichine, L., Falkowski, P.G., Cardol, P., Bowler, C. \& Finazzi, G. 2015. Energetic coupling between plastids and mitochondria drives $\mathrm{CO}_{2}$ assimilation in diatoms. Nature 524:366.

Bargu, S., Powell, C.L., Wang, Z., Doucette, G.J. \& Silver, M.W. 2008. Note on the occurrence of Pseudo-nitzschia australis and domoic acid in squid from Monterey Bay, CA (USA). Harmful Algae 7:45-51.

Bates, S., Garrison, D. \& Horner, R. 1998. Bloom dynamics and physiology producing Pseudonitzschia species. In Anderson, D.M., Cembella, A.D. \& Hallegraeff, G.M. [Eds.]. Physiological ecology of harmful algal bloomsSpringer-Verlag. Heidelberg, p. 267-292.

Bates, S.S., Hiltz, M.F. \& Léger, C. 1999. Domoic acid toxicity of large new cells of Pseudo-nitzschia multiseries resulting from sexual reproduction. Sixth Can. Work. Harmful Mar. Algae. 21-6.

Baugh, K.A., Bush, J.M., Bill, B.D., Lefebvre, K.A. \& Trainer, V.L. 2006. Estimates of specific toxicity in several Pseudo-nitzschia species from the Washington coast, based on culture and field studies. Afr. J. Mar. Sci. 28:403-7.

Brunson, J.K., Mckinnie, S.M.K., Chekan, J.R., Mccrow, J.P., Miles, Z.D., Bertrand, E.M., Bielinski,

This article is protected by copyright. All rights reserved. 
V.A., Luhavaya, H., Obornik, M., Smith, G.J., Hutchins, D.A., Allen, A.E. \& Moore, B.S. 2018. Biosynthesis of the neurotoxin domoic acid in a bloom-forming diatom. Science 365:1356-8.

Calu, G., Martin-Jezequel, V., Lefau, E., Sechet, V., Lassus, P., Weigel, P., \& Amzil, Z. 2009. The influence of nitrogen speciation on growth and toxicity of Pseudo-nitzschia multiseries and $P$. pungens in batch and continuous cultures. In Seventh International Conference on Molluscan Shellfish Safety, Éditions Qua, Nantes (p. 7).

Chepurnov, V.A., Mann, D.G., Sabbe, K., Vannerum, K., Casteleyn, G., Verleyen, E., Peperzak, L. and Vyverman, W. 2005. Sexual reproduction, mating system, chloroplast dynamics and abrupt cell size reduction in Pseudo-nitzschia pungens from the North Sea (Bacillariophyta). Eur. J. Phycol. 40:379-95.

Chepurnov, V.A., Mann, D.G., Sabbe, K. \& Vyverman, W. 2004. Experimental studies on sexual reproduction in Diatoms. Int. Rev. Cytol. 237:91-154.

Chisholm, S.W. \& Costello, J.C. 1980. Influence of environmental factors and population composition on the timing of cell division in Thalassiosira fluviatilis (Bacillariophyceae) grown on light/dark cycles. J. Phycol. 16: 375-83.

Cusack, C., Raine, R. \& Patching, J.W. 2004. Occurrence of species from the genus Pseudo-nitzschia peragallo in Irish waters. Biol. Environ. 104:55-74.

Cusack, C.K., Bates, S.S., Quilliam, M.A., Patching, J.W. \& Raine, R. 2002. Confirmation of domoic acid production by Pseudo-nitzschia australis (Bacillariophyceae) isolated from Irish waters. $J$. Phycol. 28: 604-7.

D’Alelio, D., Amato, A., Luedeking, A. \& Montresor, M. 2009. Sexual and vegetative phases in the planktonic diatom Pseudo-nitzschia multistriata. Harmful Algae 8:225-32.

D’Alelio, D., D'Alcalà, M.R., Dubroca, L., Sarno, D., Zingone, A. \& Montresor, M. 2010. The time for sex: A biennial life cycle in a marine planktonic diatom. Limnol. Oceanogr. 55:106-14.

Davidovich, N.A. 1994. Factors controlling the size of initial cells in diatoms. Russ. J. Plant Physiol. 41:220-4.

Davidovich, N.A., Kaczmarska, I. \& Ehrman, J.M. 2010. Heterothallic and homothallic sexual reproduction in Tabularia fasciculata (Bacillariophyta). Fottea 10:251-66.

Davidovich, N. A., Gastineau, R., Gaudin, P., Davidovich, O.I. \& Mouget, J.L. 2012. Sexual reproduction in the newly-described blue diatom, Haslea karadagensis. Fottea 12:219-29.

This article is protected by copyright. All rights reserved. 
Davidovich, N. a \& Bates, S.S. 1998. Sexual reproduction in the pennate diatoms Pseudo-nitzschia multiseries and P. pseudodelicatissima (Bacillariophyceae). J. Phycol. 34:126-37.

Edlund, M.B. \& Bixby, R.J. 2001. Intra- and inter-specific differences in gametangial and initial cell size in diatoms. Proceedings of the 16th international diatom symposium. Vol. 25. Athens: Faculty of Biology, University of Athens.

Edlund, M.B. \& Stoermer, E.F. 1997. Ecological, evolutionary, and systematic significance of diatom life histories. J. Phycol. 33:897-918.

Edwards, K.F., Thomas, M.K., Klausmeier, C.A. \& Litchman, E. 2012. Allometric scaling and taxonomic variation in nutrient utilization traits and maximum growth rate of phytoplankton. Limnol. Oceanogr. 57:554-66.

Fehling, J., Davidson, K., Bolch, C.J. \& Bates, S.S. 2004. Growth and domoic acid production by Pseudo-nitzschia seriata (Bacillariophyceae) under phosphate and silicate limitation. J. Phycol. 40:674-83.

Fernandes, L.F., Hubbard, K. A., Richlen, M.L., Smith, J., Bates, S.S., Ehrman, J., Léger, C., Mafra Jr. L.L., Kulis, D., Quilliam, M., Libera, K., McCauley, L. \& Anderson, D.M. 2014. Diversity and toxicity of the diatom Pseudo-nitzschia Peragallo in the Gulf of Maine, Northwestern Atlantic Ocean. Deep. Res. Part II Top. Stud. Oceanogr. 103:139-62.

Frenkel, J., Vyverman, W. \& Pohnert, G. 2014. Pheromone signaling during sexual reproduction in algae. Plant J. 79:632-44.

Frøsig Gai, F., Kirketerp Hedemand, C., Louw, D.C. \& Grobler, K. 2018. Morphological, molecular and toxigenic characteristics of Namibian Pseudo-nitzschia species - including Pseudonitzschia bucculenta sp . nov . Harmful Algae 76:80-95.

Fuchs, N., Scalco, E., Kooistra, W.H.C.F., Assmy, P. \& Montresor, M. 2013. Genetic characterization and life cycle of the diatom Fragilariopsis kerguelensis. Eur. J. Phycol. 48:411-26.

Fuchs, N., Scalco, E., Kooistra, W.H.C.F., Assmy, P. \& Montresor, M. 2013. Genetic characterization and life cycle of the diatom Fragilariopsis kerguelensis. Eur. J. Phycol. 48:411-26.

Garrison, D., Conrad, S., Eilers, P. \& Waldrom, E. 1992. Confirmation of domoic acid production by Pseudo-nitzschia australis (Bacillariophyceae) cultures. J. Phycol. 28:604-7.

Godhe, A. \& Rynearson, T. 2017. The role of intraspecific variation in the ecological and evolutionary success of diatoms in changing environments. Philos. T. R. Soc. B 372.1728: 20160399.

This article is protected by copyright. All rights reserved. 
Guillard, J., Frenkel, J., Devos, V., Sabbe, K., Paul, C., Rempt, M., Inzé, D., Pohnert, G., Vuylsteke, M., \& Vyverman, W. 2013. Metabolomics enables the structure elucidation of a diatom sex pheromone. Angew. Chemis Int. Ed. 52:854-7.

Hamm, C.E., Merkel, R., Springer, O., Jurkojc, P., Maier, C., Prechtel, K. \& Smetacek, V. 2003. Architecture and material properties of diatom shells provide effective mechanical protection. Nature 421: 841.

Harðardóttir, S., Pančić, M., Tammilehto, A., Krock, B., Møller, E., Nielsen, T. \& Lundholm, N. 2015. Dangerous relations in the Arctic marine food web: Interactions between toxin producing Pseudo-nitzschia diatoms and Calanus Copepodites. Mar. Drugs 13:3809-35.

Hasle, G.R. 2002. Are most of the domoic acid-producing species of the diatom genus Pseudonitzschia cosmopolites? Harmful Algae 1:137-46.

Hense, I. \& Beckmann, A. 2015. A theoretical investigation of the diatom cell size reductionrestitution cycle. Ecol. Modell. 317:66-82.

Hiltz, M., Bates, S.S. \& Kaczmarska, I. 2000. Effect of light: dark cycles and cell apical length on the sexual reproduction of the pennate diatom Pseudo-nitzschia multiseries (Bacillariophyceae) in culture. Phycologia 39:59-66.

Holtermann, K.E., Bates, S.S., Trainer, V.L., Odell, A. \& Armbrust, E.V. 2010. Mass sexual reproduction in the toxigenic diatoms Pseudo-nitzschia australis and P. pungens (Bacillariophyceae) on the Washington coast, USA. J. Phycol. 46:41-52.

Howard, M.D.A., Cochlan, W.P., Ladizinsky, N. \& Kudela, R.M. 2007. Nitrogenous preference of toxigenic Pseudo-nitzschia australis (Bacillariophyceae) from field and laboratory experiments. Harmful Algae 6:206-17.

Jewson, D.H. 1992. Size reduction, reproductive strategy and the life cycle of a centric diatom. Phil. Trans. R. Soc. Lond. B 336.1277: 191-213.

Kaczmarska, I., Pouličková, A., Sato, S., Edlund, M.B., Idei, M., Watanabe, T. \& Mann, D.G. 2013. Proposals for a terminology for diatom sexual reproduction, auxospores and resting stages. Diatom Res. 28: 1-32.

Keller, M.D., Selvin, R.C., Claus, W. \& Guillard, R.R.. 1987. Media for the culture of oceanic ultraphytoplankton. J. Phycol. 23:633-8.

Klein, C., Claquin, P., Bouchart, V., Le Roy, B. \& Véron, B. 2010. Dynamics of Pseudo-nitzschia spp. and domoic acid production in a macrotidal ecosystem of the Eastern English Channel

This article is protected by copyright. All rights reserved. 
(Normandy, France). Harmful Algae 9:218-26.

Lakeman, M.B., von Dassow, P. \& Cattolico, R.A. 2009. The strain concept in phytoplankton ecology. Harmful Algae 8:746-58.

Lelong, A., Hégaret, H., Soudant, P. \& Bates, S.S. 2012. Pseudo-nitzschia (Bacillariophyceae) species, domoic acid and amnesic shellfish poisoning : revisiting previous paradigms. Phycologia 51:168-216.

Lema, K.A., Latimier, M., Nézan, É., Fauchot, J. \& Le Gac, M. 2017. Inter- and intra-specific growth and domoic acid production in relation to nutrient ratios and concentrations in Pseudo-nitzschia: phosphate an important factor. Harmful Algae 64:11-9.

Lewis, W.M. 1984. The diatom sex clock and its evolutionary significance. Am. Nat. 123.1: 73-80.

Lewis, W.M. 1987. The cost of sex. In Stearns, S.C. [Eds.] The evolution of sex and its consequences. Experientia Supplementum 55:33-57.

Li, Y., Huang, C.X., Xu, G.S., Lundholm, N., Teng, S.T., Wu, H. \& Tan, Z. 2017. Pseudo-nitzschia simulans sp. nov. (Bacillariophyceae), the first domoic acid producer from Chinese waters. Harmful Algae 67:119-30.

Lim, H.C., Lim, P.T., Teng, S.T., Bates, S.S. \& Leaw, C.P. 2014. Genetic structure of Pseudonitzschia pungens (Bacillariophyceae) populations: Implications of a global diversification of the diatom. Harmful Algae 37:142-52.

Lim, H.C., Teng, S.T., Leaw, C.P. \& Lim, P.T. 2013. Three novel species in the Pseudo-nitzschia pseudodelicatissima complex: P. batesiana sp. nov., P. lundholmiae sp. nov., and P. fukuyoi sp. nov. (Bacillariophyceae) from the Strait of Malacca, Malaysia. J. Phycol. 49:902-16.

Liu, H., Kelly, M.S., Campbell, D. a, Dong, S.L., Zhu, J.X. \& Wang, S.F. 2007. Exposure to domoic acid affects larval development of king scallop Pecten maximus (Linnaeus, 1758). Aquat. Toxicol. 81:152-8.

Lundholm, N., Daugbjerg, N. \& Moestrup, Ø. 2002. Phylogeny of the Bacillariaceae with emphasis on the genus Pseudo-nitzschia (Bacillariophyceae) based on partial LSU rDNA. Eur. J. Phycol. 37:115-34.

Lundholm, N., Hansen, P.J. \& Kotaki, Y. 2005. Lack of allelopathic effects of the domoic acidproducing marine diatom Pseudo-nitzschia multiseries. Mar. Ecol. Prog. Ser. 288:21-33.

Mafra, L.L., Bricelj, V.M., Ouellette, C., Léger, C. \& Bates, S.S. 2009. Mechanisms contributing to

This article is protected by copyright. All rights reserved. 
low domoic acid uptake by oysters feeding on Pseudo-nitzschia cells. I. Filtration and pseudofeces production. Aquat. Biol. 6:201-12.

Maldonado, M.T., Hughes, M.P., Rue, E.L. \& Wells, M.L. 2002. The effect of Fe and $\mathrm{Cu}$ on growth and domoic acid production by Pseudo-nitzschia multiseries and Pseudo-nitzschia australis. Limnol. Oceanogr. 47:515-26.

Mann, D.G. 1999. The species concept in diatoms. Phycologia 38:437-95.

Mann, D.G., Chepurnov, V.A. \& Idei, M. 2003. Mating system, sexual reproduction, and auxosporulation in the anomalous raphid diatom Eunotia (Bacillariophyta). J. Phycol. 39:106784.

Mann, D.G. \& Vanormelingen, P. 2013. An inordinate fondness? the number, distributions, and origins of diatom species. J. Eukaryot. Microbiol. 60:414-20.

Marañón, E., Cermeño, P., López-Sandoval, D.C., Rodríguez-Ramos, T., Sobrino, C., Huete-Ortega, M., Blanco, J.M. \& Rodriguez, J. 2013. Unimodal size scaling of phytoplankton growth and the size dependence of nutrient uptake and use. Ecol. Lett. 16:371-9.

Martin-Jézéquel, V., Calu, G., Candela, L., Amzil, Z., Jauffrais, T., Séchet, V. \& Weigel, P. 2015. Effects of organic and inorganic nitrogen on the growth and production of domoic acid by Pseudo-nitzschia multiseries and P. australis (Bacillariophyceae) in culture. Mar. Drugs 13:7067-86.

Not, F., Siano, R., Kooistra, W.H.C.F., Simon, N., Vaulot, D. \& Probert, I. 2012. Diversity and ecology of eukaryotic marine phytoplankton. Advances in Botanical Research. 64: 1-53.

Orive, E., Pérez-Aicua, L., David, H., García-Etxebarria, K., Laza-Martínez, A., Seoane, S. \& Miguel, I. 2013. The genus Pseudo-nitzschia (Bacillariophyceae) in a temperate estuary with description of two new species: Pseudo-nitzschia plurisecta sp. nov. and Pseudo-nitzschia abrensis sp. nov. J. Phycol. 49:1192-206.

Otero, J., Bode, A., Álvarez-salgado, X.A. \& Varela, M. 2018. Role of functional trait variability in the response of individual phytoplankton species to changing environmental conditions in a coastal upwelling zone. Mar. Ecol. Prog. Ser. 596:33-47.

Pan, Y., Bates, S.S. \& Cembella, A.D. 1998. Environmental stress and domoic acid production by Pseudo-nitzschia: a physiological perspective. Nat. Toxins 6:127-35.

Pan, Y., Subba Rao, D., Mann, K.H., Rg, B. \& Pocklington, R. 1996a. Effects of silicate limitation on production of domoic acid, a neurotoxin, by the diatom Pseudo-nitzschia multiseries. I. Batch

This article is protected by copyright. All rights reserved. 
culture studies. Mar. Ecol. Prog. Ser. 131: 225-33.

Pan, Y., Subba Rao, D. V \& Mann, K.H. 1996b. Changes in domoic acid production and cellular chemical composition of the toxigenic diatom Pseudo-nitzschia multiseries under phosphate limitation. Mar. Ecol. Prog. Ser. 131: 235-43.

Quijano-Scheggia, S., Garcés, E., Andree, K.B., De la Iglesia, P., Diogène, J., Fortuño, J.M. \& Camp, J. 2010. Pseudo-nitzschia species on the Catalan coast: characterization and contribution to the current knowledge of the distribution of this genus in the Mediterranean Sea. Sci. Mar. 74:395410.

Radan, R.L. \& Cochlan, W.P. 2018. Differential toxin response of Pseudo-nitzschia multiseries as a function of nitrogen speciation in batch and continuous cultures, and during a natural assemblage experiment. Harmful Algae 73:12-29.

Rhodes, L., Jiang, W., Knight, B., Adamson, J., Smith, K., Langi, V. \& Edgar, M. 2013. The genus Pseudo-nitzschia (Bacillariophyceae) in New Zealand: Analysis of the last decade's monitoring data. New Zeal. J. Mar. Freshw. Res. 47:490-503.

Santiago-Morales, I.S. \& García-Mendoza, E. 2011. Growth and domoic acid content of Pseudonitzschia australis isolated from northwestern Baja California, Mexico, cultured under batch conditions at different temperatures and two $\mathrm{Si}: \mathrm{NO}_{3}$ ratios. Harmful Algae 12:82-94.

Sato, S., Beakes, G., Idei, M., Nagumo, T. \& Mann, D.G. 2011. Novel sex cells and evidence for sex pheromones in diatoms. PLOS ONE 6: e26923.

Schwarz, R., Wolf, M. \& Müller, T. 2009. A probabilistic model of cell size reduction in Pseudonitzschia delicatissima (Bacillariophyta). J. Theor. Biol. 258:316-22.

Smeti, E., Roelke, D.L., Gremion, G., Linhart, J.M., Danielidis, D.B. \& Spatharis, S. 2015. Potential mechanisms of coexistence between two globally important Pseudo-nitzschia (Bacillariophyta) species. Hydrobiologia 762:89-101.

Sobrinho, B.F., De Camargo, L.M., Sandrini-Neto, L., Kleemann, C.R., Da Costa Machado, E. \& Mafra, L.L. 2017. Growth, toxin production and allelopathic effects of Pseudo-Nitzschia multiseries under Iron-enriched conditions. Marine Drugs 15:331.

Tammilehto, A., Nielsen, T.G., Krock, B., Møller, E.F. \& Lundholm, N. 2015. Induction of domoic acid production in the toxic diatom Pseudo-nitzschia seriata by calanoid copepods. Aquat. Toxicol. 159:52-61.

Teng, S.T., Lim, H.C., Lim, P.T., Dao, V.H., Bates, S.S. \& Leaw, C.P. 2014. Pseudo-nitzschia

This article is protected by copyright. All rights reserved. 
kodamae sp. nov. (Bacillariophyceae), a toxigenic species from the Strait of Malacca, Malaysia. Harmful Algae 34:17-28.

Teng, S.T., Tan, S.N., Lim, H.C., Dao, V.H., Bates, S.S. \& Leaw, C.P. 2016. High diversity of Pseudo-nitzschia along the northern coast of Sarawak (Malaysian Borneo), with descriptions of P. bipertita sp. nov. and P. limii sp. nov. (Bacillariophyceae)1. J. Phycol. 52: 973-89.

Thessen, A. E., Bowers, H. a. \& Stoecker, D.K. 2009. Intra- and interspecies differences in growth and toxicity of Pseudo-nitzschia while using different nitrogen sources. Harmful Algae 8:792810.

Thorel, M., Fauchot, J., Morelle, J., Raimbault, V., Le Roy, B., Miossec, C., Kientz-Bouchart, V. \& Claquin, P. 2014. Interactive effects of irradiance and temperature on growth and domoic acid production of the toxic diatom Pseudo-nitzschia australis (Bacillariophyceae). Harmful Algae 39:232-41.

Thorel, M., Claquin, P., Schapira, M., Le Gendre, R., Riou, P., Goux, D., Le Roy, B., Raimbault, V., Deton-Cabanillas, A.F., Bazin, P., Kientz-Bouchart, V. \& Fauchot, J. 2017. Nutrient ratios influence variability in Pseudo-nitzschia species diversity and particulate domoic acid production in the Bay of Seine (France). Harmful Algae 68:192-205.

Trainer, V.L., Bates, S.S., Lundholm, N., Thessen, A.E., Cochlan, W.P., Adams, N.G. \& Trick, C.G. 2012. Pseudo-nitzschia physiological ecology, phylogeny, toxicity, monitoring and impacts on ecosystem health. Harmful Algae 14:271-300.

Van Meerssche, E., Greenfield, D.I. \& Pinckney, J.L. 2018. Coastal eutrophication and freshening: Impacts on Pseudo-nitzschia abundance and domoic acid allelopathy. Estuar. Coast. Shelf Sci. 209:70-9.

Vanormelingen, P., Vanelslander, B., Sato, S., Gillard, J., Trobajo, R., Sabbe, K. \& Vyverman, W. 2013. Heterothallic sexual reproduction in the model diatom Cylindrotheca. Eur. J. Phycol. 48:93-105.

Villac, M.C., Roelke, D.L., Chavez, F.P., Cifuentes, L.A. \& Fryxell, G.A. 1993. Pseudo-nitzschia australis Frenguelli and related species from the west coast of the U.S.A.: occurrence and domoic acid production. J. Shellfish Res. 12:457-65.

Von Dassow, P., Chepurnov, V.A. \& Armbrust, E.V. 2006a. Relationships between growth rate, cell size, and induction of spermatogenesis in the centric diatom Thalassiosira weissflogii (Bacillariophyta). J. Phycol. 42:887-99.

This article is protected by copyright. All rights reserved. 
Table 1. Strains of Pseudo-nitzschia australis, P. pungens, and P. fraudulenta used for mating and batch culture experiments. (A) for strains isolated from the Atlantic and (EC) for strains isolated from the English Channel. The age of the strain (in months, calculated from the date of isolation) and the cell size length (cell size) are indicated for each experiment.

\begin{tabular}{|c|c|c|c|c|c|}
\hline \multirow[b]{2}{*}{ Species } & \multicolumn{3}{|c|}{ Strain information } & \multirow[b]{2}{*}{$\begin{array}{l}\text { Age of strain } \\
\text { (month) }\end{array}$} & \multirow[b]{2}{*}{ Cell size length $(\mu \mathrm{m})$} \\
\hline & $\begin{array}{l}\text { Collection } \\
\text { reference }\end{array}$ & $\begin{array}{l}\text { Origin (Sampling } \\
\text { zone or crossing) }\end{array}$ & $\begin{array}{c}\text { Isolation } \\
\text { date }\end{array}$ & & \\
\hline \multirow[t]{9}{*}{ P. australis } & IFR-PAU-010 & Ouessant $(\mathrm{A})$ & $07 / 2015$ & 5 & 50 \\
\hline & PNaus P1D2 & $\begin{array}{l}\text { Camaret-sur-Mer } \\
\text { (A) }\end{array}$ & $03 / 2014$ & 21 & 44 \\
\hline & PNaus P3B2 & Plouzané (A) & 03/2014 & 21 & 49 \\
\hline & PNaus 02T & Arcachon Bay (A) & $04 / 2016$ & $9-12-14-16$ & $69-63-60-57$ \\
\hline & PNaus P6B3 & Plouzané (A) & $04 / 2014$ & $20-26$ & $42-35$ \\
\hline & PNaus F1-1A & $\mathrm{P} 6 \mathrm{~B} 3 \times \mathrm{P} 2 \mathrm{~B} 1$ & & & 83 \\
\hline & PNaus F1-4A & $\mathrm{P} 6 \mathrm{~B} 3 \times \mathrm{P} 6 \mathrm{C} 1$ & & & 73 \\
\hline & PNaus F1-5 & $\mathrm{P} 6 \mathrm{~B} 3 \times \mathrm{P} 1 \mathrm{~A} 3$ & & & $97-82-65-61-57$ \\
\hline & PNaus F2-1B & F1-5 x F1-1A & & & $127-106$ \\
\hline \multirow[t]{13}{*}{ P. pungens } & PNpun 47 & Cabourg (EC) & $08 / 2011$ & 59 & 48 \\
\hline & PNpun 66 & Ouistreham (EC) & $09 / 2011$ & $51-58$ & $41-47$ \\
\hline & PNpun 79 & Cabourg (EC) & $05 / 2012$ & 50 & 52 \\
\hline & PNpun 88 & Cabourg (EC) & $07 / 2012$ & 48 & 47 \\
\hline & PNpun 89 & Cabourg (EC) & $07 / 2012$ & $41-48$ & $42-49$ \\
\hline & PNpun 129 & Luc-sur-mer (EC) & $07 / 2016$ & 2 & 75 \\
\hline & PNpun 130 & Luc-sur-mer (EC) & $07 / 2016$ & 2 & 95 \\
\hline & PNpun 133 & Luc-sur-mer (EC) & $07 / 2016$ & 3 & 109 \\
\hline & PNpun 134 & Luc-sur-mer (EC) & $07 / 2016$ & 3 & 102 \\
\hline & PNpun 136 & $\begin{array}{l}\text { Saint-Vaast-la- } \\
\text { Hougue (EC) }\end{array}$ & 07/2016 & 3 & 85 \\
\hline & PNpun F1-7A & $66 \times 89$ & & & $157-175$ \\
\hline & PNpun F1-7B & $66 \times 89$ & & & 153 \\
\hline & PNpun F1-11 & $66 \times 47$ & & & 153 \\
\hline \multirow[t]{12}{*}{ P. fraudulenta } & PNfra 1 & Cabourg (EC) & $08 / 2011$ & 62 & 27 \\
\hline & PNfra 10 & Cabourg (EC) & 08/2011 & $51-59$ & $45-39$ \\
\hline & PNfra 30 & Cabourg (EC) & $10 / 2011$ & $49-57$ & $41-36$ \\
\hline & PNfra 31 & COMOR 41 (EC) & $07 / 2011$ & 64 & 31 \\
\hline & PNfra 126 & Luc-sur-mer (EC) & $11 / 2015$ & 3 & 65 \\
\hline & PNfra 132 & Luc-sur-mer (EC) & $10 / 2015$ & 3 & 68 \\
\hline & PNfra 162 & $\begin{array}{l}\text { Saint-Vaast-la- } \\
\text { Hougue (EC) }\end{array}$ & $05 / 2016$ & 5 & 69 \\
\hline & PNfra F1-8D & $30 \times 31$ & & & $107-87$ \\
\hline & PNfra F1-9A & $10 \times 31$ & & & 78 \\
\hline & PNfra F1-9B & $10 \times 31$ & & & $113-92$ \\
\hline & PNfra F1-14A & $10 \times 1$ & & & 110 \\
\hline & PNfra F1-14B & $10 \times 1$ & & & 113 \\
\hline
\end{tabular}

This article is protected by copyright. All rights reserved. 
Figure 1. Mean size of initial cells as a function of mean size of parent strains in Pseudo-nitzschia australis, $P$. pungens, and $P$. fraudulenta. Standard deviations represent the minimum and maximum sizes measured for initial cells and represent the variance for parental cells.

Figure 2. Size range of vegetative cells (white) and gametangia (grey and hatched pattern) in Pseudonitzschia australis, P. pungens, and P. fraudulenta. Crosses and dots correspond to cell sizes for which mating experiments were performed. Crosses: no sexual reproduction observed. Hatched pattern and white dots: incomplete sexual reproduction observed (without initial cell production). Light grey and dark grey dots: complete sexual reproduction observed (with initial cell production). The size percentage was calculated based on the maximal initial size. 85 mating experiments were made to define the gametangia size range for $P$. australis, 40 for $P$. pungens, and 89 for $P$. fraudulenta. 193 cells were measured to determine the vegetative cell size range for $P$. australis, 334 cells for $P$. pungens, and 551 cells for $P$. fraudulenta.

Figure 3. (A) Growth rate $\left(\mu, \mathrm{d}^{-1}\right)$ as a function of the age of the strains (months) since their isolation from natural populations in Pseudo-nitzschia australis $(\mathrm{n}=9), P$. pungens $(\mathrm{n}=12)$, and $P$. fraudulenta $(\mathrm{n}=9$; F1 strains from sexual reproduction are not present in this graph). (B) Growth rate $\left(\mu, \mathrm{d}^{-1}\right)$ as a function of the cell size $(\mu \mathrm{m})$ for all strains studied in $P$. australis $(\mathrm{n}=18), P$. pungens $(\mathrm{n}$ $=16)$, and $P$. fraudulenta $(\mathrm{n}=16)$.

Figure 4. Cellular domoic acid content ( $\left.\mathrm{cDA}, \mathrm{fg} \cdot \mathrm{cell}^{-1}\right)$ as a function of cell size $(\mu \mathrm{m}):(\mathrm{A})$ in Pseudo-nitzschia australis and (B) in P. pungens and P. fraudulenta. Data come from the cDA measurements made in the batch experiments on the second day of the stationary phase linked to a phosphate or silicate limitation.

Figure 5. Dissolved domoic acid (dDA, fg $\left.\cdot \operatorname{cell}^{-1}\right)$ as a function of cell size $(\mu \mathrm{m})$ : (A) in Pseudonitzschia australis and (B) in P. pungens and P. fraudulenta. Data come from the dDA measurements made in the batch experiments on the second day of the stationary phase linked to a phosphate or silicate limitation.

This article is protected by copyright. All rights reserved. 
Figure 6. Monitoring of the cellular domoic acid content $\left(\mathrm{cDA}, \mathrm{fg} \cdot \mathrm{cell}^{-1}\right)$ of four strains of Pseudonitzschia australis during their decrease in cell size.

Figure S1. Optical microscopy observation of Pseudo-nitzschia australis strain (PNaus P6B3) with abnormal valve shapes in small cells.

Figure S2. Relationship between cell size and strain age (month) since their isolation from the natural environment in Pseudo-nitzschia australis $(\mathrm{n}=9)$, . pungens $(\mathrm{n}=12)$, and P. fraudulenta $(\mathrm{n}=9)(\mathrm{F} 1$ strains are not taken into account). Linear regressions are not significant $(\mathrm{P}>0.05)$.

Figure S3. Cellular domoic acid content $\left(\mathrm{cDA}, \mathrm{fg} \cdot\right.$ cell $^{-1}$, mean $\left.\pm \mathrm{SD}\right)$ under phosphate limitation (black bars) or silicate limitation (grey bars) in Pseudo-nitzschia australis $(\mathrm{n}=18)$, . pungens $(\mathrm{n}=$ 16), and $P$. fraudulenta $(\mathrm{n}=16)$. The letters $\mathrm{a}, \mathrm{b}$ and $\mathrm{c}$ indicate the significant differences $(\mathrm{P}<0.001)$.

Figure S4. Cellular domoic acid content $\left(\mathrm{cDA}, \mathrm{fg} \cdot \mathrm{cell}^{-1}\right)$ as a function of the age of the strain (months) since their isolation from natural populations: (A) in Pseudo-nitzschia australis $(\mathrm{n}=9)$ and (B) in P. pungens $(\mathrm{n}=12)$ and $P$. fraudulenta $(\mathrm{n}=9)$.

Figure S5. Dissolved domoic acid (dDA, fg $\cdot$ cell $\left.^{-1}\right)$ as a function of the age of the strain (months) since their isolation from natural populations: (A) Pseudo-nitzschia australis $(\mathrm{n}=9)$ and (B) in $P$. pungens $(\mathrm{n}=12)$ and P. fraudulenta $(\mathrm{n}=9)$.

This article is protected by copyright. All rights reserved. 


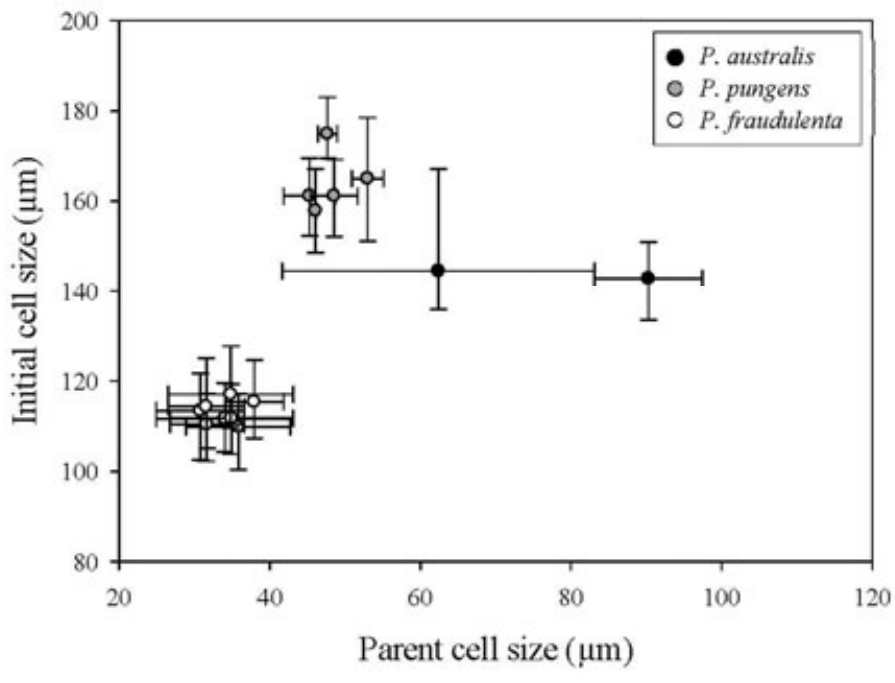

This article is protected by copyright. All rights reserved. 


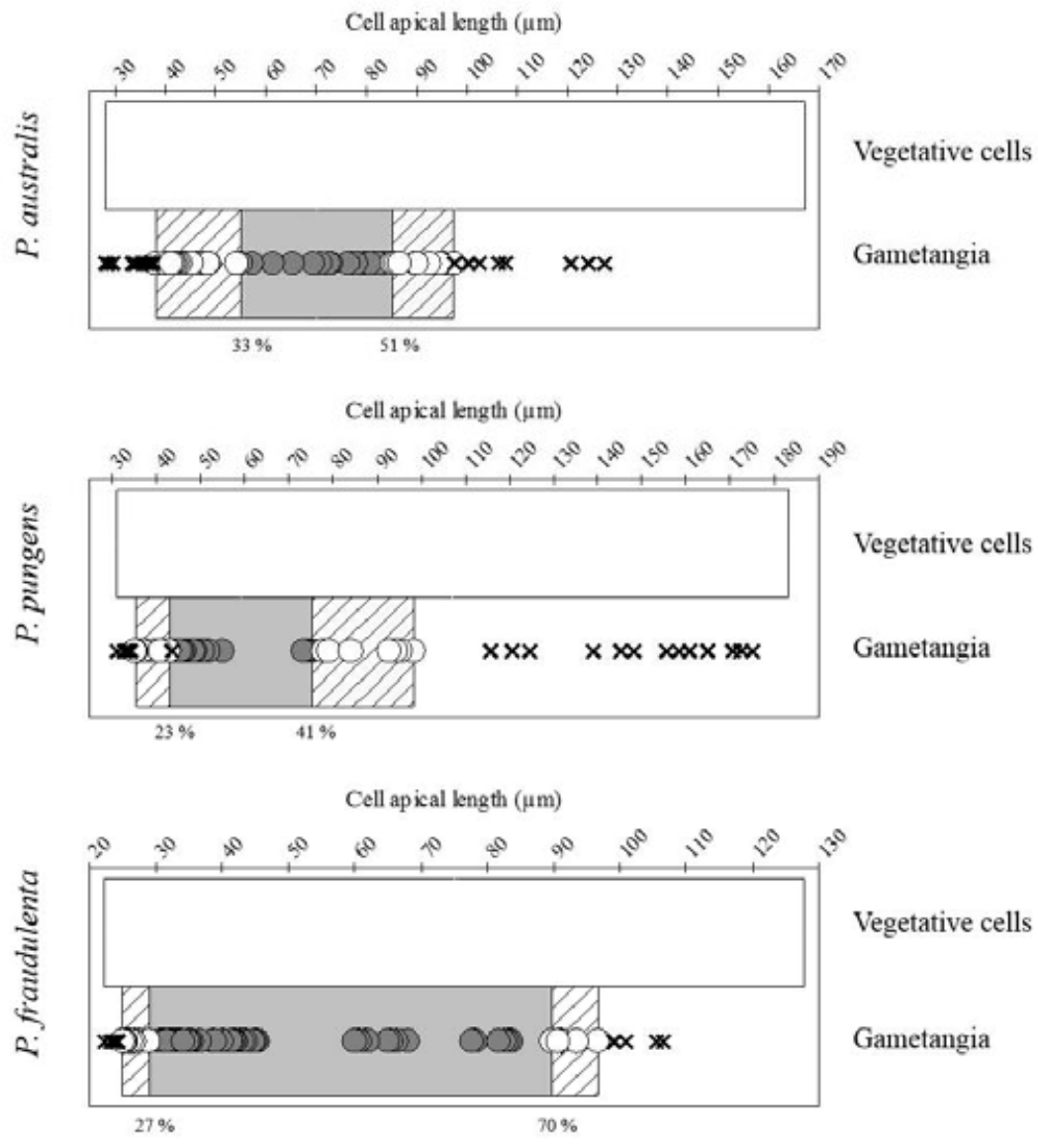

This article is protected by copyright. All rights reserved. 

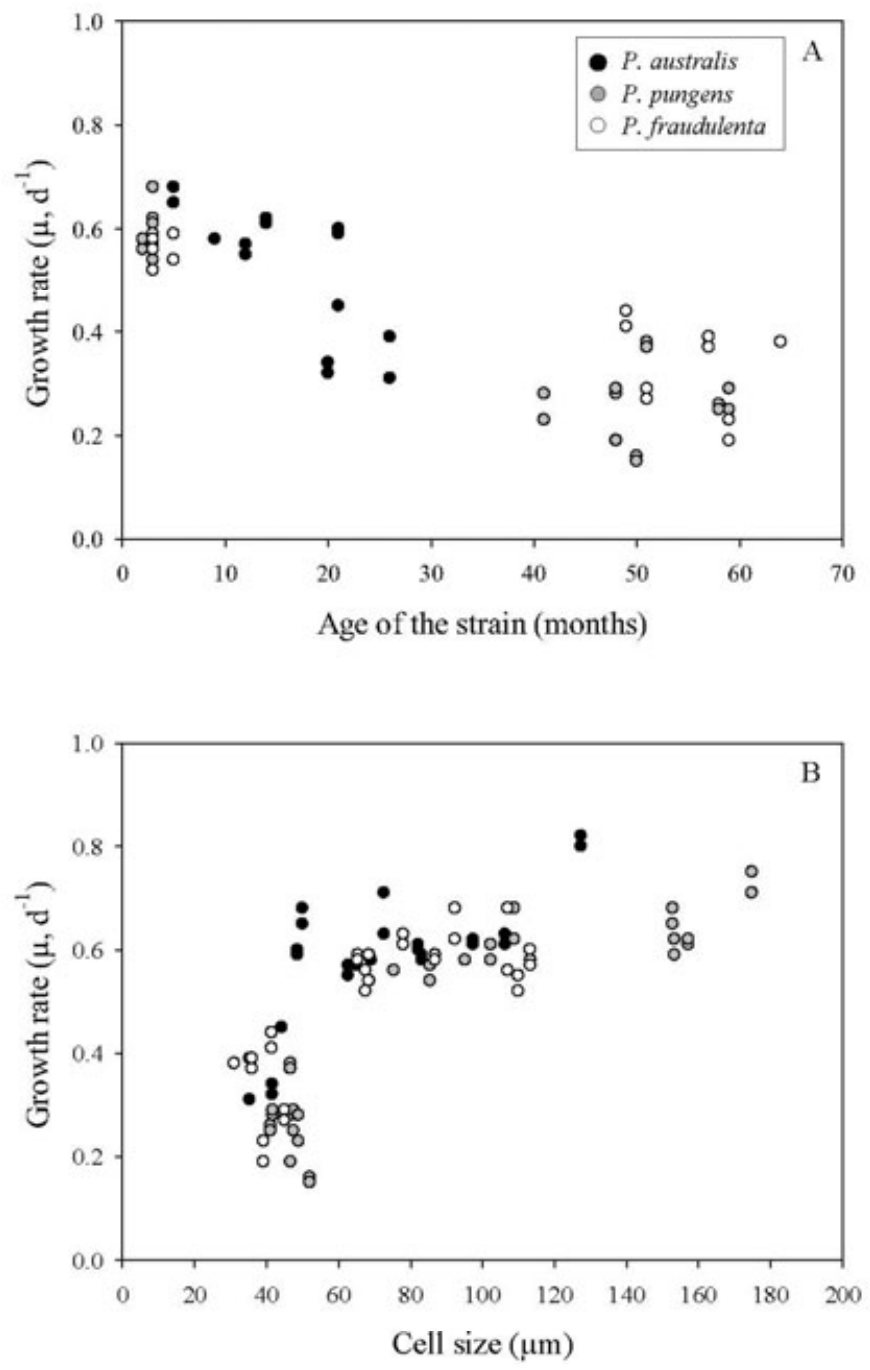

This article is protected by copyright. All rights reserved. 

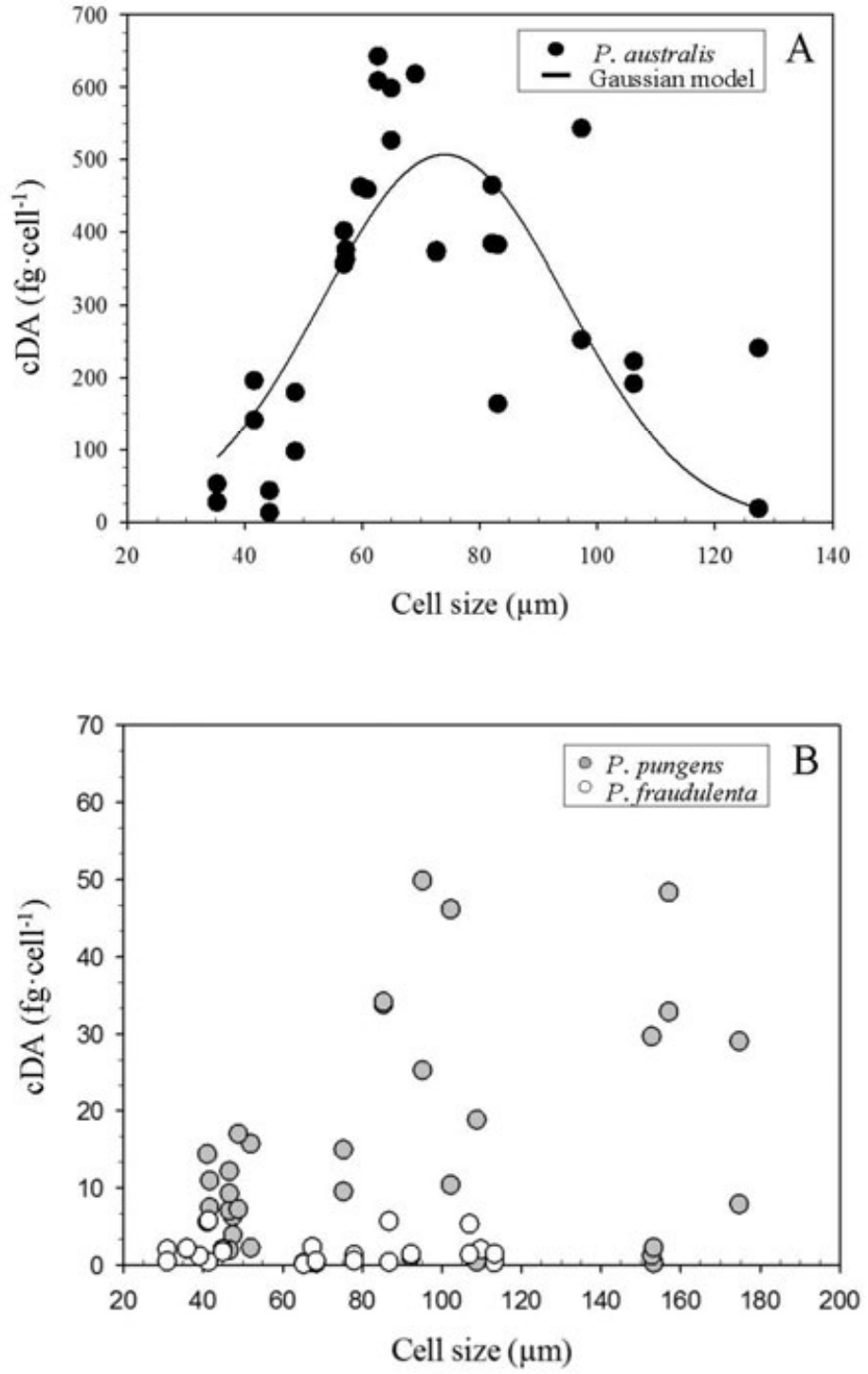

This article is protected by copyright. All rights reserved. 

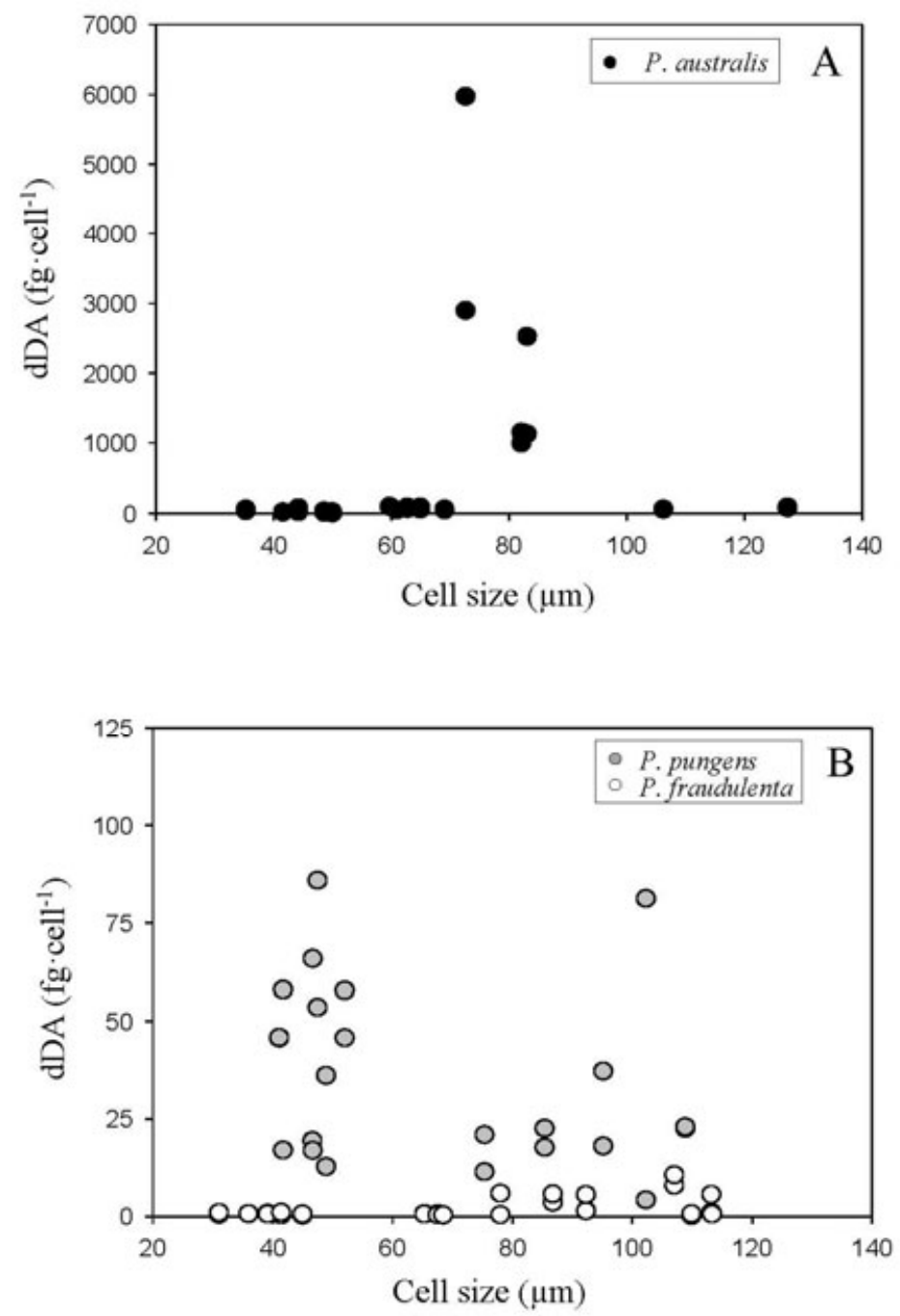

This article is protected by copyright. All rights reserved. 


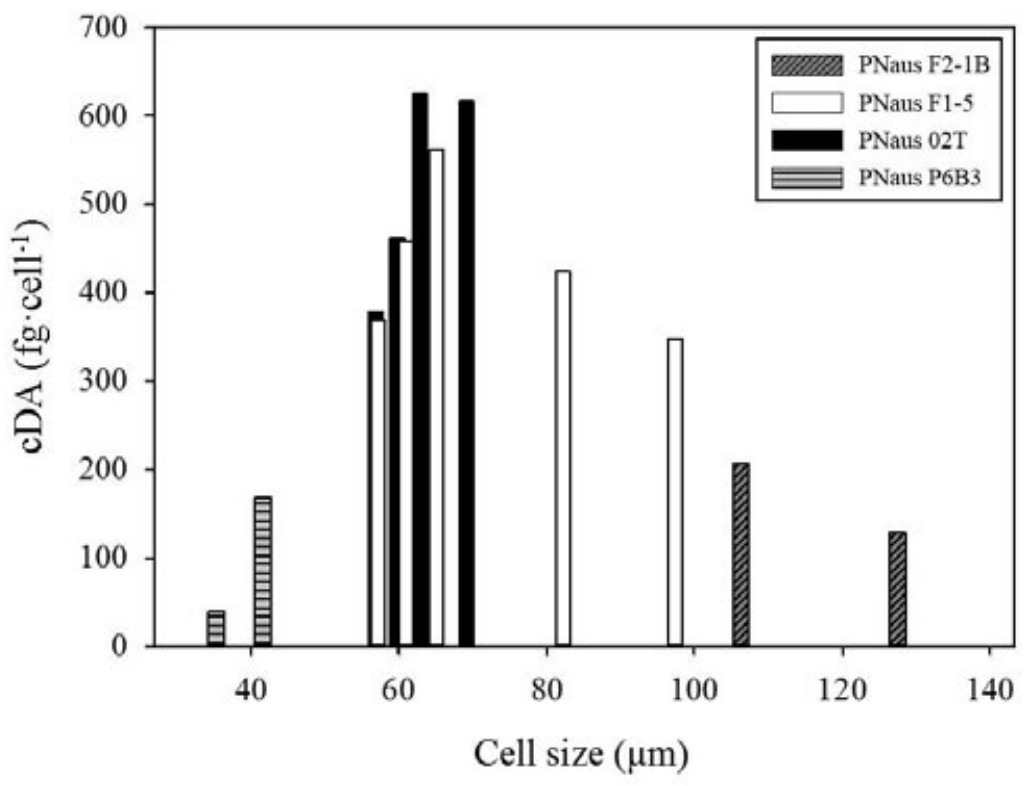

This article is protected by copyright. All rights reserved. 